\title{
Geochemistry and petrogenesis of the early Palaeozoic appinite-granite complex in the Western Kunlun Orogenic Belt, NW China: implications for Palaeozoic tectonic evolution
}

\author{
JIE ZHU*, QIUGEN LI*†, XU CHEN \\ YANJING CHEN*, SHUWEN LIU*, BING XIAO* \& JUNLU CHEN\| \\ * The Key Laboratory of Orogenic Belts and Crustal Evolution, Ministry of Education, School of Earth and Space \\ Sciences, Peking University, Beijing 100871, China \\ $\$$ Department of Energy and Mineral Engineering, Pennsylvania State University, University Park, Pennsylvania \\ 16802, US \\ §State Key Laboratory of Ore Deposit Geochemistry, Institute of Geochemistry, Chinese Academy of Sciences, \\ Guiyang 550008, China \\ qInstitute of Mineral Resources, Chinese Academy of Geological Sciences, Beijing 100037, China \\ „Xi'an Institute of Geology and Mineral Resource, Xi'an 710054, China
}

(Received 19 October 2016; accepted 25 April 2017; first published online 17 July 2017)

\begin{abstract}
The Datong pluton, the largest early Palaeozoic granitoid in the Western Kunlun Orogenic Belt (WKOB) in NW China, is a typical appinite-granite complex. It consists of diorites, quartz diorites, monzodiorites, quartz monzodiorites, monzonites, quartz monzonites, syenites, granodiorites and monzogranites. Laser ablation inductively coupled plasma mass spectrometry (LA-ICP-MS) zircon $\mathrm{U}-\mathrm{Pb}$ dating yielded crystallization ages of $459 \pm 3 \mathrm{Ma}$ for the quartz monzonites and $452 \pm 5 \mathrm{Ma}$ for the monzogranites (Late Ordovician). The rocks possess a wide range of $\mathrm{SiO}_{2}(56.0-73.4 \mathrm{wt} \%), \mathrm{MgO}$ (0.17-4.55 wt \%) and $\mathrm{Mg}$ no. (25-60), with high $\mathrm{K}_{2} \mathrm{O}(2.83-5.29$ wt \%) contents, exhibiting high-K calc-alkaline to shoshonitic traits. They are characterized by enrichments in large-ion lithophile elements (LILEs) and light rare Earth elements (LREEs), as well as depletions in high-field-strength elements (HFSEs). The rocks have initial ${ }^{87} \mathrm{Sr} /{ }^{86} \mathrm{Sr}$ ratios of $0.7086-0.7185$, negative $\varepsilon_{\mathrm{Nd}}(\mathrm{t})$ values of -3.72 to -1.79 and $\varepsilon_{\mathrm{Hf}}(\mathrm{t})$ values vary from -1.6 to +4.7 . These features are modelled to show that they were most likely derived from an enriched lithospheric mantle source and that fractional crystallization with minor crustal contamination was involved in their petrogenetic process. Considering the distribution and chronology of the Palaeozoic intrusions - such as Kegang, Bulong, Qiukesu, Yierba, North Kudi, Dongbake, Buya, Ayilixi and Warengzilafu granitoid plutons with ages of c. 420-530 Ma - in conjunction with the Palaeozoic metamorphic overprinting in the WKOB, we propose a divergent double-subduction model to explain the destruction of the Proto-Tethys Ocean and suggest that the Datong pluton was likely emplaced in a post-collisional setting following the termination of subduction in response to slab break-off.
\end{abstract}

Keywords: Appinite-granite, zircon U-Pb dating, geochemistry, double subduction, Western Kunlun Orogenic Belt.

\section{Introduction}

The Western Kunlun Orogenic Belt (WKOB), located at the NW border of the Tibetan Plateau, forms the western segment of the Qinling-Qilian-Kunlun Orogenic Belt (also referred to as the Central Orogenic Belt; Jiang, Wang \& Li, 2000) which transects eastern Asia and, via the bending of the tectonic fabric, terminates eastwards into the approximately N-S-trending Sulu Orogenic Belt (Fig. 1a). The WKOB occupies a key tectonic position at the junction between the Pan-Asian and Tethyan tectonic domains; study of the WKOB therefore plays an important role in the reconstruction of Gondwana and Laurasia during early Pa-

†Author for correspondence: qgli@pku.edu.cn laeozoic - late Mesozoic time. During the last two decades, intensive international research has demonstrated that the WKOB formed through collision between the Tarim Craton and Karakoram-Qiangtang Terrane during Late Triassic - Early Jurassic time (Deng, 1995; Matte et al. 1996; Pan, 1996; Mattern \& Schneider, 2000; Xiao et al. 2002, 2005; Li, Ji \& Yang, 2008) and was subjected to Cenozoic deformation due to the far-field effects of the India-Asia collision along the southern margin of the Tibetan Plateau (Yin \& Harrison, 2000). With a focus on the Early Palaeozoic tectonic evolution, the recent integration of geology, geochemistry, isotope geochemistry and geochronology has demonstrated that an active continental margin related to the subduction of the Proto-Tethys Ocean may have been present along the southern boundary of 


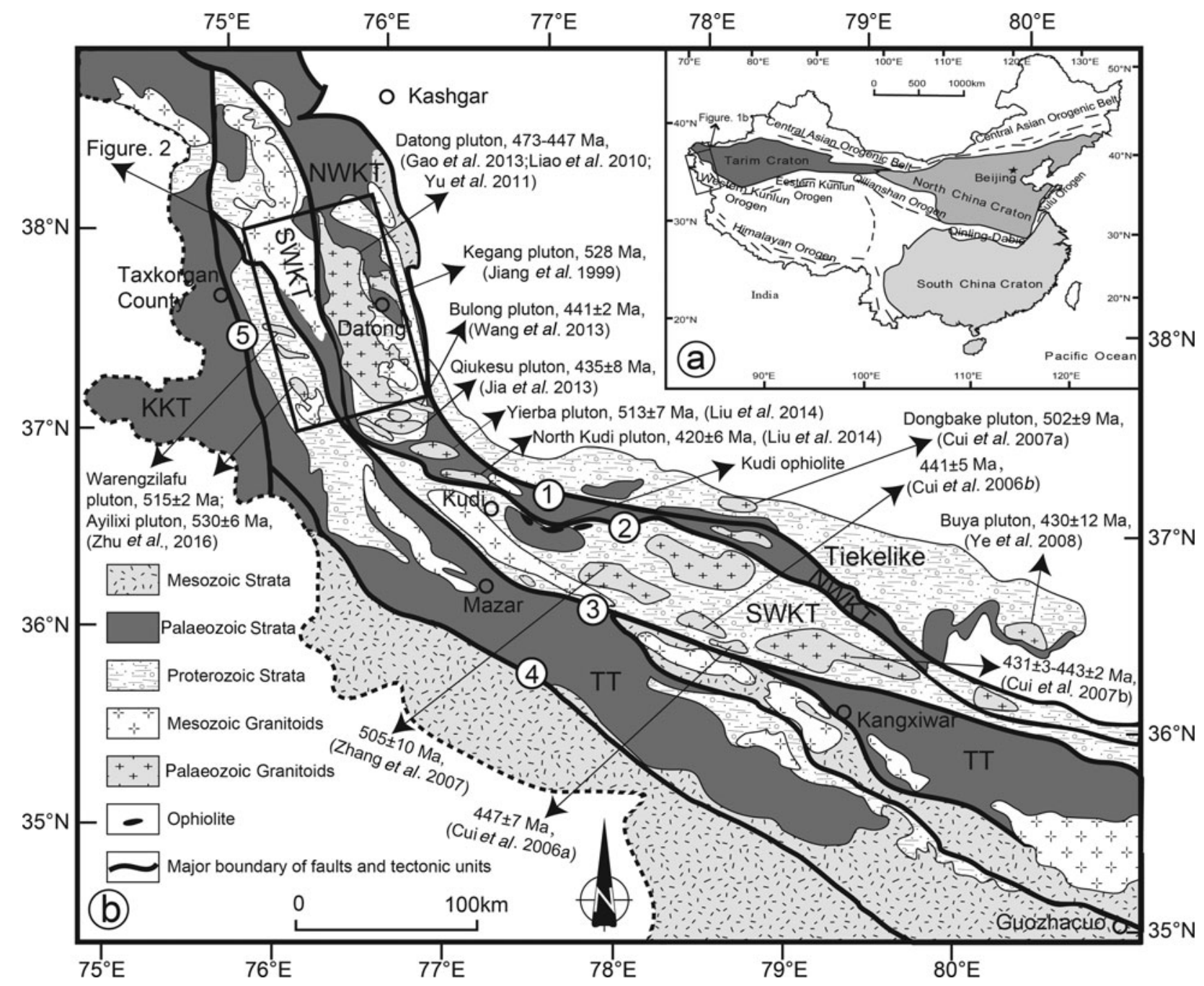

Figure 1. (a) Schematic tectonic map of China, showing the major cratons and orogenic belts in mainland China (modified after Li et al. 2007; Zhao \& Cawood, 2012). The location of the Western Kunlun Orogenic Belt (Fig. 1b) is shown by the rectangle. (b) Geological sketch map showing tectonic division of the Western Kunlun Orogenic Belt and distribution of the Palaeozoic and Mesozoic granitoids in the NW and SW Kunlun Terrane (modified after Li, Ji \& Yang, 2008; Pan, 1996). Location of the Datong pluton (Fig. 2) is shown by the rectangle. NWKT - NW Kunlun Terrane; SWKT - SW Kunlun Terrane; TT - Tianshuihai Terrane; KKT - Karakoram Terrane. 1, Oytag-Kegang Fault (OKF); 2, Kudi Fault (KF); 3, Mazar-Kangxiwar Fault (MKF); 4, Longmucuo-Shuanghu Fault (LSF); 5, Karakoram Fault (KKF).

the Tarim Craton since Cambrian or Ordovician time (Deng et al. 1995; Matte et al. 1996; Pan, 1996; Jiang et al. 1999, 2002; Mattern \& Schneider, 2000; Xiao et al. 2002, 2005; Wang, 2004; Li, Ji \& Yang, 2008; Ye et al. 2008; Liao et al. 2010; Jia et al. 2013; Liu et al. 2014). Nevertheless, some controversies regarding the exact timing of Proto-Tethys Ocean termination as well as its subduction polarity in the WKOB remain. Some models assumed the southwards subduction of the Proto-Tethys Ocean (Mattern \& Schneider, 2000; Liao et al. 2010; Jia et al. 2013; Liu et al. 2014), with collision between the NW and SW Kunlun terranes occurring during Late Ordovician - early Silurian time (Fig. 1b; Matte et al. 1996; Pan, 1996; Mattern \& Schneider, 2000; Ye et al. 2008; Liao et al. 2010; Jia et al. 2013; Liu et al. 2014). Other models favoured northwards-dipping subduction that resulted in subsequent collision between the NW and SW Kunlun terranes during Late Ordovician - Devonian time
(Deng, 1995; Wang, 2004; Li et al. 2007). Xiao et al. $(2002,2005)$ argued that the late Cambrian - Early Ordovician southwards-dipping subduction of the ProtoTethys Ocean might have switched to northwardsdipping subduction, thereby generating the Andeantype arc plutons during Middle Ordovician time.

Petrogenetic understanding of magmas provides key insights into geodynamic processes. Detailed mapping and geochronological data revealed that the Palaeozoic granitoids were emplaced in both the NW and SW Kunlun terranes and that the intrusions are distributed mainly close to the Kudi Fault (Fig. 1b). As the largest of the Palaeozoic plutons within the WKOB, the Datong pluton can provide crucial information on the tectonic evolution in this region (Jiang et al. 2002; Liao et al. 2010; Yu et al. 2011; Gao et al. 2013). However, different petrogenetic and tectonic models have been proposed to explain the formation of the intrusion. According to Liao et al. (2010), the Datong 
pluton can be considered a product of Ordovician continental arc magmatism originating from partial melting of the mantle wedge modified by subducted sediments. Jiang et al. (2002) suggested that the magmatic activity of the Datong pluton reflects the transition from crustal thickening associated with final collision and the onset of extensional collapse of the orogen. In contrast, some authors (Yu et al. 2011; Gao et al. 2013) attributed the Datong plutonism to an extensional tectonic regime related to asthenospheric upwelling, which triggered the generation of the parental magmas. As the focus of our systematic investigation, including previously obtained geochemical data (Jiang et al. 2002; Liao et al. 2010; Yu et al. 2011; Gao et al. 2013), we found that the Datong pluton had magmatic rock types ranging continuously from subordinate mafic types to the main body of monzonite, quartz monzonite, syenite and granite with high$\mathrm{K}$ calc-alkaline to shoshonitic affinities. These rocks contain mineralogical and textural features that are indicative of water-rich magmas and form a typical appinite-granite complex.

Appinites are more common than previously realized. They have been identified in different orogens on many different continents and range in age from late Archean to Recent (Pitcher, 1997; Murphy, 2013). These rock suites are usually associated with coeval granitoids and have genetic linkages with several enigmatic rock suites such as shoshonites, sanukitoids, TTG suites, adakites and high-Mg andesites (Castro et al. 2003; Murphy, 2013). Additionally, they are petrogenetically related to deep crustal faults and significant geodynamic processes, such as post-subduction slab break-off and delamination during the latest stages of an orogeny (Murphy \& Hynes, 1990; Atherton \& Ghani, 2002; Castro et al. 2003; Ye et al. 2008; Murphy, 2013). Constraining the origin and tectonic affiliation of appinites can therefore provide important clues to sources of orogenic magmas and contribute to the understanding of the tectonic evolution of ancient convergent plate margins. The objective of this research is therefore to determine the tectonic evolution of the Palaeozoic magmatism by using new and reported petrological, geochemical and isotopic data from the WKOB (Fig. 1). In this contribution, we present a comprehensive study of the Datong pluton, including field observations, petrography, zircon $\mathrm{U}-\mathrm{Pb}$ dating, zircon $\mathrm{Hf}$ isotopic compositions, whole-rock geochemistry and $\mathrm{Sr}-\mathrm{Nd}$ isotopic compositions. Based on these data, we can explore the petrogenesis of the pluton and provide important insights into the Palaeozoic tectonic evolution of the WKOB.

\section{Geological setting and geology of the Datong pluton}

\section{2.a. Geological setting}

As the NW boundary of the Tibetan Plateau, the WKOB is exposed along the southern flank of the
Tarim Craton over a length of $1000 \mathrm{~km}$. It is subdivided into the NW Kunlun terrane (NWKT), SW Kunlun terrane (SWKT) and Tianshuihai terrane (TT), according to the boundaries formed by the Oytag-Kegang Fault (OKF), Kudi Fault (KF), Mazar-Kangxiwar Fault (MKF), Longmucuo-Shuanghu Fault (LSF) and Karakoram Fault (KKF) (Fig. 1b; Mattern et al. 1996; Pan, 1996; Mattern \& Schneider, 2000; Xiao et al. 2002; Zhang et al. 2007; Li, Ji \& Yang, 2008).

The NWKT is delimited by the OKF to the north and the KF to the south and is generally considered to be an extension of the Tarim Craton. It features a double-layered structure consisting of a Palaeoproterozoic-Mesoproterozoic basement overlain by a Neoproterozoic-Cambrian cover series (Jiang, Wang \& $\mathrm{Li}, 2000)$. The basement rocks of the NWKT, characterized by amphibolite-facies gneisses, migmatites and schists, are mostly exposed in the Akazi-Xuxugou region of the NWKT and in the Tiekelike uplift belt (Matte et al. 1996; Jiang, Wang \& Li, 2000; Mattern \& Schneider, 2000). The Tiekelike uplift belt is regarded as the folded basement of the Tarim Craton (Cui et al. 2006c; Wang et al. 2014), which was intruded by the Dongbake pluton $(502 \pm 9 \mathrm{Ma}$; Cui et al. 2007a) and the Buya pluton (430 $12 \mathrm{Ma}$; Ye et al. 2008) (Fig. 1b). The oldest-known age of the Heluostan complex is 2.26$2.42 \mathrm{Ga}$, and the complex was overprinted by c. $2.0 \mathrm{Ga}$ and $1.8 \mathrm{Ga}$ metamorphic events (Wang et al. 2014). The overlying slightly metamorphosed Mesoproterozoic - early Neoproterozoic sequences include continental rift volcano-sedimentary deposits. Moreover, middle-late Neoproterozoic anorogenic magmatism coeval with the rift-related igneous activities in the Tarim Craton is documented in the NWKT. These Mesoproterozoic-Neoproterozoic geological records are interpreted to be associated with the break-up of the Rodinia supercontinent (Zhao \& Cawood, 2012). Sporadic, early Palaeozoic volcano-sedimentary strata rest unconformably on metamorphic Precambrian rocks and many lower Palaeozoic granitoids, such as the Datong, Kegang, Bulong, Youlun, Qiukesu, Quepuhe, Yierba and North Kudi granitoid plutons with ages of c. 420-528 Ma, intruded the Precambrian and lower Palaeozoic units (Jiang et al. 1999, 2002; Xiao et al. 2005; Yuan et al. 2005; Cui et al. 2007a; Liao et al. 2010; Jia et al. 2013; Liu et al. 2014) and are exposed along the KF in the NWKT (Fig. 1b). Above these units, Upper Devonian terrestrial red molasse deposits grade upwards into shallow-marine Carboniferous and Permian carbonates and clastic sediments (Matte et al. 1996; Jiang, Wang \& Li, 2000; Mattern \& Schneider, 2000; Wang, 2004).

The SWKT is characterized by a gneiss complex and the Kudi ophiolite mélange. Pan (1996) first demonstrated that the Kudi ophiolite mélange represents a significant tectonic line separating the NWKT and SWKT (Fig. 1b). This ophiolite mélange represents an obducted ophiolite unit that was emplaced in the SWKT. The available age information for this ophi- 
olite favours its formation during early Palaeozoic time (526-506 Ma; Matte et al. 1996; Mattern et al. 1996; Mattern \& Schneider, 2000; Pan, 1996; Wang, 2004; Ye et al. 2008). Recently, Li \& Zhang (2014) determined the zircon LA-ICP-MS U-Pb ages of $494 \pm 1 \mathrm{Ma}$ and $500 \pm 8 \mathrm{Ma}$ for websterite in an ultramafic body in the Buziwan valley and dolerite in extrusive rocks in the Yixieke valley, respectively, further demonstrating that the ultramafic body and the extrusive rocks are members of the Kudi ophiolite and were generated during late Cambrian time. The geochemical characteristics of lavas in the Kudi ophiolite mélange suggest that they were produced in a subduction initiation setting (Yuan et al. 2005) or early rifting stage of an oceanic basin (Yang et al. 1996; Wang, 2004; Yuan et al. 2005). The gneiss complex, which forms within the main topographic ridge of the $\mathrm{WKOB}$, is chiefly composed of biotite/hornblende gneisses with minor lenses of schist, marble, phyllite, quartzite and amphibolite that are intruded by basic and acidic dykes. The complex has been interpreted as a Proterozoic microcontinent derived from the Tarim Craton (Matte et al. 1996; Pan, 1996) or as a metamorphosed Palaeozoic accretionary subduction complex (Xiao et al. 2002, 2005). The ${ }^{40} \mathrm{Ar} /{ }^{39} \mathrm{Ar}$ age spectra from hornblende $(452 \pm 5 \mathrm{Ma})$ and biotite (428 $\pm 2 \mathrm{Ma}$ ) and zircon SHRIMP U-Pb dating (445-428 Ma) of the gneisses, coupled with kinematic indicators, show that these rocks were affected by Late Ordovician - early Silurian local ductile shearing (Matte et al. 1996; Zhou et al. 2000; Xu et al. 2007). Similar to the NWKT, a pre-Devonian stratigraphic gap exists in the SWKT, and no stratigraphy exists between these metamorphic gneissic rocks and the unconformably overlying Upper Devonian molasses. Granitic intrusions, which are dominantly Palaeozoic and subordinately Mesozoic in age, outcrop in the north and in the south of the SWKT, respectively (Fig. 1b; Cui et al. 2006a, b; Zhang et al. 2007).

The TT, adjoining the Karakoram Terrane to the south, is separated by the KKF in the west and the LSF in the SW (Fig. 1b). For a long time, this terrane was interpreted as a huge accretionary wedge that formed through northwards subduction of the PalaeoTethys Ocean beneath the SWKT (Mattern et al. 1996; Mattern \& Schneider, 2000; Xiao et al. 2002, 2005; Wang, 2004). The Permian-Triassic rocks are dominated by flyschoid facies exposed in the northeastern part of the TT, which can be correlated with the Bayan Har Belt further east (Matte et al. 1996; Mattern et al. 1996; Li, Ji \& Yang, 2008). In the southern part of the TT there are two different metamorphic units: a high-grade metamorphosed crystalline basement that includes the Palaeoproterozoic Bulunkuole Group and the Meso-Neoproterozoic Tianshuihai Group, which contain minor mafic rocks and high-pressure granulite (Qu et al. 2007; Ji et al. 2011); and an overlying upper Cambrian - Triassic metasedimentary succession that reaches a thickness of up to $13 \mathrm{~km}$ and has properties of continental to shallow-marine deposits (Jiang, Wang $\& \mathrm{Li}, 2000)$. Based on the stratigraphic similarity, Ji et al. (2011) correlated this metasedimentary unit to a metasedimentary unit in the northern part of the Qiangtang Block. Recently, Zhu et al. (2016) identified two early Palaeozoic plutons that intruded into the Palaeoproterozoic Bulunkuole Group: these plutons have zircon U-Pb ages of $530 \pm 6 \mathrm{Ma}$ (a granitic porphyry in Ayilixi pluton) and $515 \pm 2 \mathrm{Ma}$ (a monzogranite in Warengzilafu pluton).

\section{2.b. Geology of the Datong pluton}

The Datong pluton is the largest of the Palaeozoic intrusions within the NWKT (Fig. 1b). Similar but smaller plutons, such as the Kegang, Bulong, Youlun, Qiukesu Quepuhe, Yierba and North Kudi plutons, are also observed to the NE and SE of the Datong pluton, in the Yierba and Kudi regions.

The Datong pluton is located to the east of Taxkorgan county and exhibits an elongated shape with an area of approximately $2000 \mathrm{~km}^{2}$. The NW-SEtrending long axis of the pluton is parallel to the KF (Fig. 1b), similar to the Greendale Complex in which structures are compatible with control by a stress field imposed by dextral motions on NE-trending Hollow and Greendale faults that bound the Antigonish Highlands of Nova Scotia (Murphy \& Hynes, 1990). It emplaced into the Proterozoic metamorphic basement and lower Palaeozoic strata and was unconformably overlain by a Carboniferous sedimentary sequence. The pluton itself was also intruded by several intrusive stocks of late Palaeozoic and Mesozoic (Fig. 2). Some metasedimentary rafts of Proterozoic and early Palaeozoic age are present in the Datong pluton, denoting their intrusive contact relationship (Fig. 2).

The Datong pluton appears as a composite or heterogeneous intrusive body, and its composition varies from mafic to felsic. The mafic compositions include diorites, quartz diorites, monzodiorites and quartz monzodiorites, and the intermediate compositions are monzonites and quartz monzonites. Among these types, monzodiorites, quartz monzodiorites, monzonites and quartz monzonites form the main body of the intrusion. Quartz diorites and diorites can be found as microgranular enclaves (Fig. 3a, b) and as a part of the pluton along the southeastern margin. The shape of these mafic microgranular enclaves varies from ovoid to angular, and they range in size from several centimetres to $0.5 \mathrm{~m}$. The angular enclaves commonly have serrated or cuspate margins with lobes convex towards the host intrusion (Fig. 3b). These features indicate that the formation of the enclaves could correspond to mafic magma pulses being injected into a partially crystallized magmatic chamber or crystal mush zone (Jerram \& Petford, 2011; Castro, 2013). However, based on field investigations, the mafic microgranular enclaves are not common, and no syn-plutonic mafic dykes are present. Felsic facies are subordinate and comprise syenites, granodiorites and monzogranites. The syenites and granodiorites are rare 

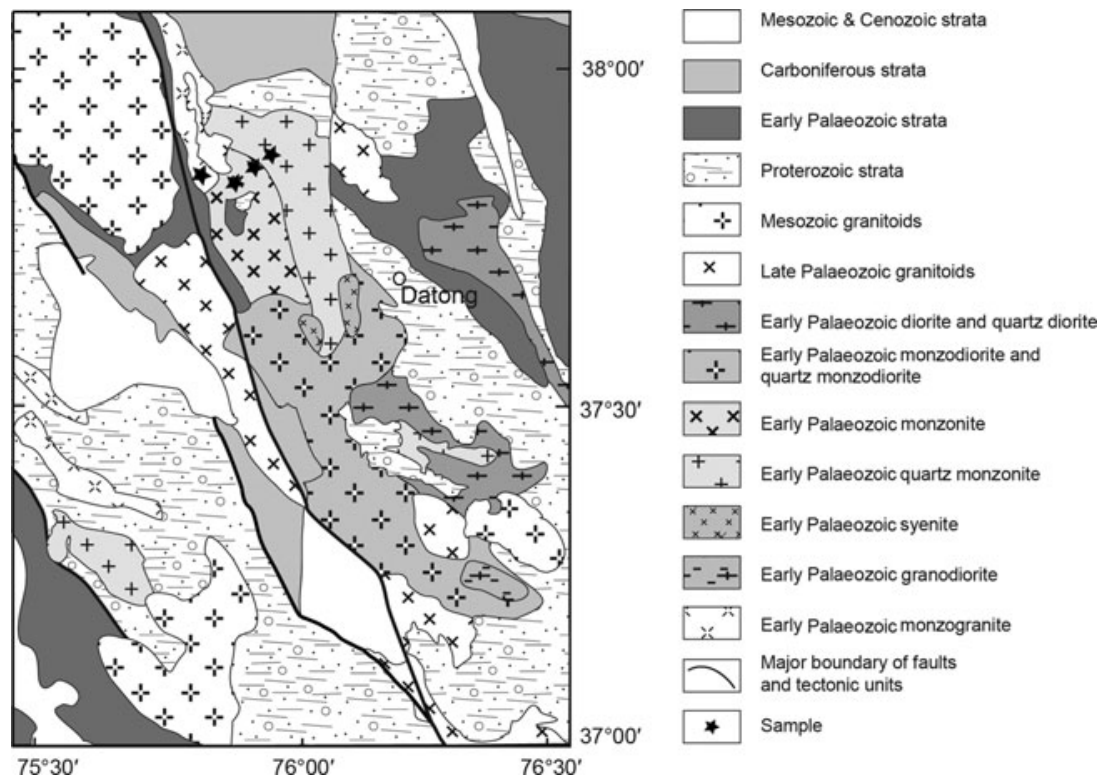

Figure 2. Simplified geological map of the Datong pluton and sampling locations.
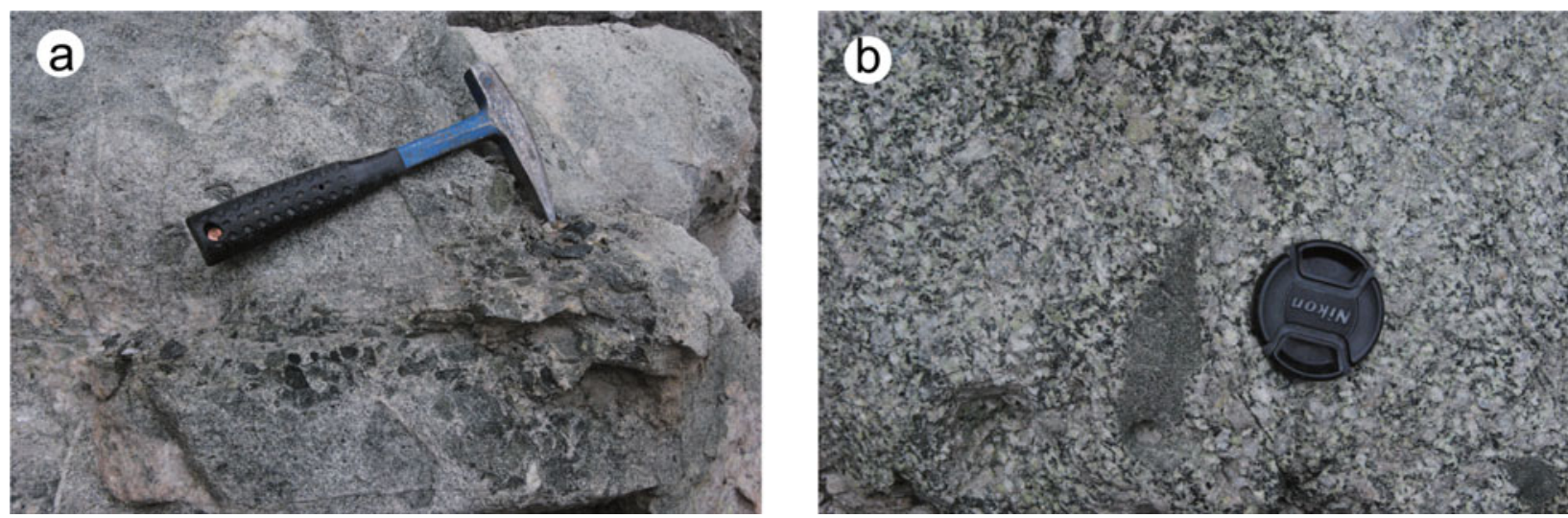

Figure 3. Photographs of typical exposures of the Datong pluton. (a) Mafic microgranular enclaves and hybrids in the granitoid; and (b) enclave as a convex lobe with cuspate margins in the host intrusions.

and mainly exposed in the central and southeastern parts of the pluton, respectively.

The contact relationships between the various lithologies are typically complex, varying from gradational to sharp, with evidence of local mingling in zones usually no more than a few metres wide which may produce hybrid rocks of intermediate composition (Fig. 4b). These compositional hybrids are characterized by high contents of mafic minerals, such as hornblende and biotite, and accessory minerals, particularly titanite and apatite. They also typically include distinctive textures, such as titanite-rich texture and poikilitic texture. Euhedral hornblendes are conspicuous in the intermediate samples 13TSK04-2, 13TSK04-3 and 13TSK04-4 (Fig. 4a, b). Additionally, titanite is present as euhedral grains disseminated throughout the rock-forming minerals in sample 13TSK04-4 (Fig. 4b), indicative of its hybrid nature. As shown in Figure 4c and d, the enclave (13TSK04-1) also displays titanite-rich and poikilitic textures which are suggestive of a hybrid composition. The water-rich tex- ture evidenced by abundant euhedral hornblendes in both the hybrids and the rest of the intermediate rocks demonstrates that the magmatic source was water-rich, coinciding with a similar feature in the appinite suites (Murphy, 2013). In addition, the poikilitic texture of the enclaves (Fig. 4d) indicates that the mafic magma was emplaced into a crystallizing magma chamber (Baxter \& Feely, 2002; Castro, 2013). Typically, the intermediate rocks and the felsic rocks usually exhibit a euhedral phenocryst of K-feldspar with concentrically more altered inclusions of plagioclase (Fig. 4e). Furthermore, the cumulative mafic minerals in the felsic monzogranite (Fig. 4f) are indicative of liquid depletion (Castro, 2013).

In this study, 13 samples were collected from the Datong pluton, including five monzonite (sample 13TSK04-4 is hybrid and is not adopted to constrain petrogenesis below), two quartz monzonite and six monzogranite samples (see Fig. 2 for sample locations). They exhibit two textural facies: equigranular and slightly porphyritic (Fig. 3b). The mineral 

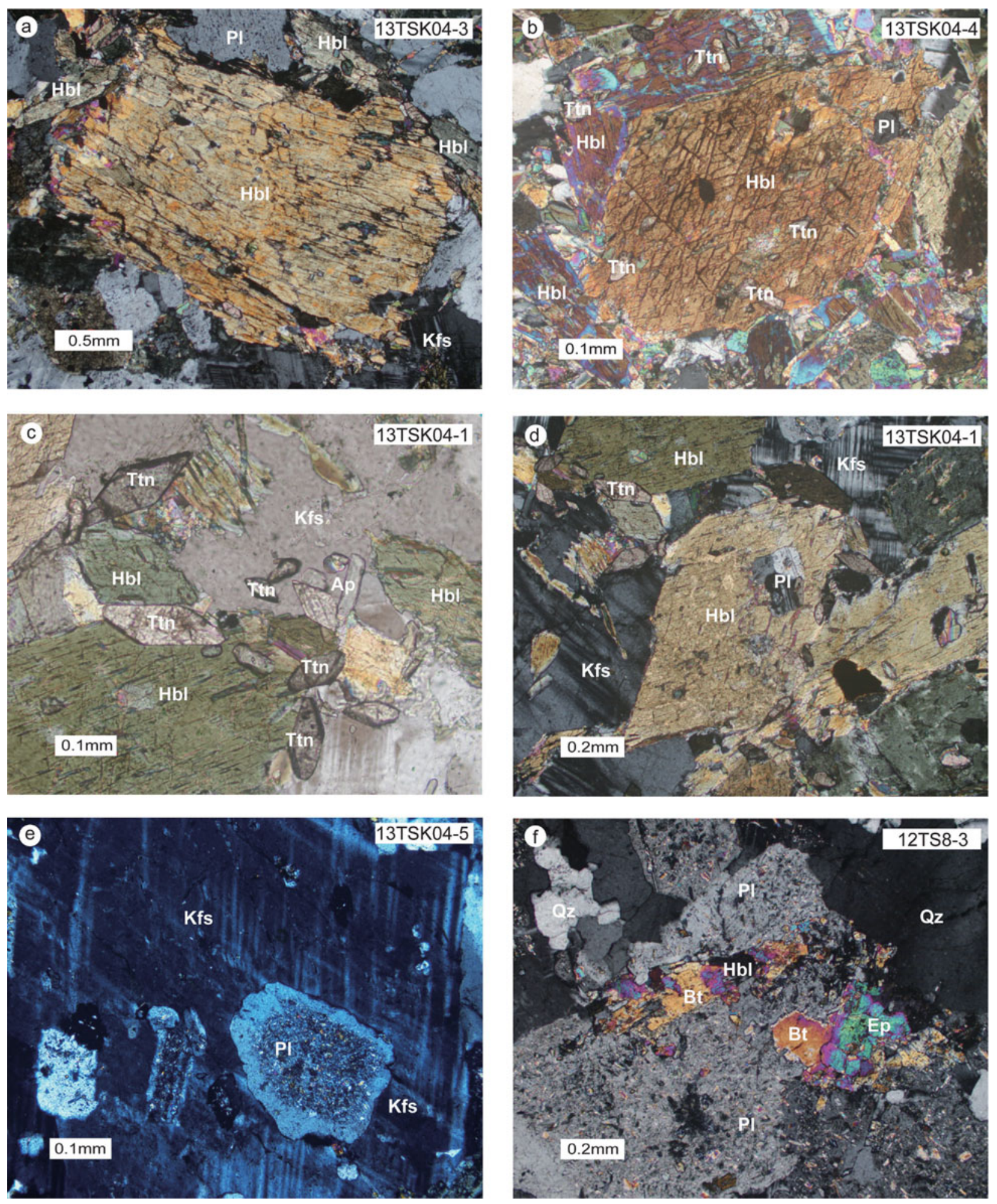

Figure 4. Photomicrographs of samples in the Datong pluton. (a) Euhedral hornblende in the intermediate rock (13TSK04-3); (b) euhedral titanites scattered throughout the rock-forming minerals indicate the hybrid nature of sample 13TSK04-4; (c, d) titaniterich texture and poikilitic texture, respectively, showing the hybrid characteristics in the enclave sample 13TSK04-1; (e) a euhedral phenocryst of K-feldspar with concentrically more altered inclusions of plagioclase in the intermediate sample 13TSK04-5; and (f) cumulative mafic minerals (e.g. Hbl, Bt, Ep) and epidotization of hornblende in the felsic monzogranite 12TS8-3. Mineral abbreviations are after Whitney \& Evans (2010).

associations are very similar between the two facies, although with modal variations. The intermediate rocks are predominantly monzonites and quartz monzonites. They show massive structures and fineto medium-grained monzonitic textures. The monzon- ites have a major mineral assemblage of $\mathrm{K}$-feldspar (35-40\%), plagioclase (18-20\%), hornblende (20$25 \%)$, biotite (2-5\%) and minor quartz, with accessory minerals of apatite, zircon, titanite, metallic minerals and others. The quartz monzonites are mainly 
composed of primary K-feldspar (35-40\%), plagioclase $(30-35 \%)$, hornblende $(8-12 \%)$, clinopyroxene $(5-10 \%)$ and quartz $(5-10 \%)$, with some biotite (5$8 \%$ ). Minor amounts of the accessory minerals apatite, titanite and zircon are detected. The felsic rocks are monzogranites, which are fine to coarse grained, feature a granitic texture and a massive structure, and contain quartz (20-30\%), K-feldspar (35-40\%), plagioclase $(25-30 \%)$, biotite $(2-3 \%)$ and hornblende $(2-3 \%)$, with accessory zircon and metallic minerals. Obvious secondary alteration, including chloritization and epidotization of biotite and hornblende and sericitization of plagioclase, indicates they have experienced deuteric processes (Fig. 4e, f).

\section{Analytical methods}

\section{3.a. Major- and trace-element analyses}

Samples were analysed at the Key Laboratory of Orogenic Belts and Crustal Evolution, Ministry of Education, School of Earth and Space Sciences, Peking University. Fresh chips of whole-rock samples were crushed into powder of below 200-mesh using an agate pulverizer. The major-element concentrations were measured using X-ray fluorescence (XRF, THERMO ARL ADVANT XP+ scanning wavelength dispersion XRF spectrometer) on fused-glass disks with a 1:10 sample to lithium metaborate flux ratio. The trace-element concentrations were measured using inductively coupled plasma mass spectrometry (ICP-MS, Agilent 7500ce ICP-MS) after acid digestion of the samples in tightly sealed $15 \mathrm{~mL}$ Teflon bombs, following the procedures of Li et al. (2007, 2011). For the trace elements, an internal standard solution including the element indium was used to monitor signal drift. The Chinese national rock standards GSR-1, GSR-3 and GSR-14 were used for analytical quality control. The analytical uncertainties for major and trace elements were generally smaller than $5 \%$ and $10 \%$, respectively.

\section{3.b. Analytical process for zircon $\mathrm{U}-\mathrm{Pb}-\mathrm{Hf}$ isotopes}

Zircons were separated using standard density and magnetic separation techniques followed by handpicking under a binocular microscope for purification. The representative zircon grains were mounted in epoxy resin and polished for optical microscope observations and cathodoluminescence (CL) imaging. The CL images were acquired with a Quanta 650 FEG high-resolution field emission scanning electron microscope prior to $\mathrm{U}-\mathrm{Pb}$ dating at the Key Laboratory of Orogenic Belts and Crustal Evolution, Ministry of Education, School of Earth and Space Sciences, Peking University.

Samples 12TS8-2 and 13TSK04-5 were analysed by LA-ICP-MS at the State Key Laboratory for Mineral Deposits Research, Nanjing University (NJU) and the State Key Laboratory of Geological Processes and
Mineral Resources, China University of Geosciences (Wuhan) (CUGW), respectively. At NJU, zircon U$\mathrm{Pb}$ analysis was performed on Agilent 7500a ICP-MS equipped with a New Wave Research $213 \mathrm{~nm}$ laser ablation system with a beam diameter of $25 \mu \mathrm{m}$. The samples were analysed in runs and each run comprised 10-12 sample analyses corrected by 4 GEMOC/GJ-1 $(608 \mathrm{Ma})$ standards. An additional well-determined reference zircon (Mud Tank, $735 \mathrm{Ma}$ ) was also analysed to control reproducibility and instrument stability. The detailed analytical procedures, precision and accuracy were as described by Jackson et al. (2004). The raw data were exported in ASCII format and offline processing was performed using GLITTER version 4.0 (Van Achterbergh et al. 2001). At CUGW, laser sampling was performed using a GeoLas 2005 laser with a spot diameter of $32 \mu \mathrm{m}$, and ion-signal intensities were acquired via the same techniques as those of NJU using an Agilent 7500a ICP-MS instrument. The detailed instrumental settings and analytical procedures are as described by Liu et al. (2010) and Xiao et al. (2014). A zircon 91500 standard was used for external standardization for $\mathrm{U}-\mathrm{Pb}$ dating and was analysed twice every five analyses. Time-dependent $\mathrm{U}-\mathrm{Th}-\mathrm{Pb}$ isotopic ratio drifts were corrected using a linear interpolation between every five analyses based on the variations in the analyses of the 91500 standard. A GJ-1 standard was treated as the internal standard for geochronologic quality control. The obtained mean ${ }^{206} \mathrm{~Pb} /{ }^{238} \mathrm{U}$ ages of the zircon standards GJ-1 and 91500 are within experimental error of their accepted values (Jackson et al. 2004). Off-line selection and integration of background and analytic signals, time-drift correction and quantitative calibration for the traceelement analyses and $\mathrm{U}-\mathrm{Pb}$ dating were performed using ICPMS DataCal 8.3 (Liu et al. 2010). For LAICP-MS U-Pb zircon results, common lead correction was performed via the Excel program $\mathrm{ComPb}$ Corr\#3.17 (Andersen, 2002), and concordia diagrams and age calculations were constructed using Isoplot $\mathrm{v}$. 3.23 (Ludwig, 2003).

For samples 12TS8-2 and 13TSK04-5, in situ LuHf isotope analysis of zircons was performed using a Thermo Fisher Scientific Neptune Plus multiple collector ICP-MS (MC-ICP-MS) at CUGW. The selected zircons dated by LA-ICP-MS were re-ablated by a Lambda Physik Geolas 2005 Excimer ArF laser ablation system with a spot size of $44 \mu \mathrm{m}$. The detailed operating conditions of the laser ablation system, the MC-ICP-MS instrument and the analytical method are described by $\mathrm{Hu}$ et al. (2012). In this study, the zircon standard 91500 yielded a weighted average ${ }^{176} \mathrm{Hf} /{ }^{177} \mathrm{Hf}$ isotopic ratio of $0.282304 \pm 0.000004$ $(2 \sigma, n=24)$, and the GJ-1 and Monastery zircon standard as unknowns yielded weighted averages of $0.282010 \pm 0.000008(2 \sigma ; n=20)$ and $0.282673 \pm 0.000007(2 \sigma, n=6)$, respectively. These results are in good agreement with the accepted 91500 ${ }^{176} \mathrm{Hf} /{ }^{177} \mathrm{Hf}$ isotopic ratio of $0.282308 \pm 0.000006$, GJ$1{ }^{176} \mathrm{Hf} /{ }^{177} \mathrm{Hf}$ isotopic ratio of $0.282015 \pm 0.000025$ 
Table 1. Major (wt \%) and trace (ppm) element analyses of the Datong pluton.

\begin{tabular}{|c|c|c|c|c|c|c|c|c|c|c|c|c|}
\hline Sample & 12TS8-2 & 12TS8-3 & $12 \mathrm{TS} 8-4$ & 12TS8-5 & 12TS9-1 & 12TS9-2 & 12TS9-3 & 13TSK04-5 & 13TSK04-2 & 13TSK04-3 & 13TSK05-1 & 13TSK05-2 \\
\hline $\mathrm{SiO}_{2}$ & 73.4 & 71.4 & 71.1 & 72.6 & 72.3 & 72.9 & 63.3 & 64.2 & 56.0 & 56.8 & 57.3 & 56.2 \\
\hline $\mathrm{TiO}_{2}$ & 0.13 & 0.15 & 0.18 & 0.13 & 0.12 & 0.12 & 0.19 & 0.47 & 1.17 & 1.26 & 0.94 & 0.98 \\
\hline $\mathrm{Al}_{2} \mathrm{O}_{3}$ & 15.0 & 15.8 & 16.0 & 14.7 & 15.4 & 15.2 & 20.3 & 16.9 & 15.6 & 14.7 & 16.6 & 16.8 \\
\hline $\mathrm{Fe}_{2} \mathrm{O}_{3}{ }^{*}$ & 1.10 & 1.44 & 1.61 & 1.16 & 1.22 & 1.19 & 1.72 & 3.38 & 6.57 & 6.84 & 6.88 & 7.30 \\
\hline $\mathrm{MnO}$ & 0.03 & 0.04 & 0.04 & 0.03 & 0.04 & 0.04 & 0.05 & 0.08 & 0.13 & 0.13 & 0.15 & 0.16 \\
\hline $\mathrm{MgO}$ & 0.48 & 0.35 & 0.42 & 0.17 & 0.25 & 0.39 & 0.98 & 1.30 & 3.93 & 4.00 & 4.43 & 4.55 \\
\hline $\mathrm{CaO}$ & 0.53 & 1.90 & 2.25 & 1.38 & 1.85 & 1.11 & 2.18 & 3.00 & 6.50 & 6.31 & 3.48 & 4.03 \\
\hline $\mathrm{Na}_{2} \mathrm{O}$ & 4.06 & 4.11 & 4.14 & 4.07 & 3.98 & 4.32 & 7.51 & 5.63 & 3.20 & 3.45 & 4.62 & 4.44 \\
\hline $\mathrm{K}_{2} \mathrm{O}$ & 4.39 & 3.89 & 3.40 & 5.29 & 4.15 & 4.01 & 2.94 & 3.76 & 4.73 & 5.08 & 2.83 & 2.86 \\
\hline $\mathrm{P}_{2} \mathrm{O}_{5}$ & 0.004 & 0.02 & 0.01 & 0.01 & 0.01 & 0.02 & 0.02 & 0.13 & 0.60 & 0.65 & 0.48 & 0.52 \\
\hline LOI & 0.75 & 0.75 & 0.59 & 0.25 & 0.51 & 0.64 & 0.70 & 1.37 & 0.50 & 0.79 & 2.02 & 1.91 \\
\hline Total & 99.8 & 99.8 & 99.8 & 99.8 & 99.8 & 99.9 & 99.9 & 100.2 & 98.9 & 100.1 & 99.8 & 99.7 \\
\hline Mg no. & 50 & 36 & 38 & 25 & 33 & 43 & 57 & 47 & 58 & 58 & 60 & 59 \\
\hline $\mathrm{Na}_{2} \mathrm{O}+\mathrm{K}_{2} \mathrm{O}$ & 8.45 & 8.00 & 7.54 & 9.36 & 8.13 & 8.33 & 10.45 & 9.39 & 7.93 & 8.53 & 7.45 & 7.30 \\
\hline $\mathrm{P}_{2} \mathrm{O}_{5} / \mathrm{TiO}_{2}$ & 0.03 & 0.13 & 0.06 & 0.08 & 0.08 & 0.17 & 0.11 & 0.28 & 0.51 & 0.52 & 0.51 & 0.53 \\
\hline $\mathrm{Rb}$ & 188 & 154 & 46 & 220 & 154 & 193 & 119 & 154 & 254 & 276 & 149 & 156 \\
\hline $\mathrm{Sr}$ & 337 & 636 & 274 & 547 & 450 & 323 & 676 & 946 & 617 & 519 & 777 & 930 \\
\hline $\mathrm{Ba}$ & 1264 & 1671 & 253 & 1618 & 1209 & 906 & 866 & 1838 & 1520 & 1566 & 1427 & 1401 \\
\hline $\mathrm{La}$ & 17 & 22 & 54 & 18 & 15.5 & 14.5 & 20 & 45 & 49 & 50 & 61 & 64 \\
\hline $\mathrm{Ce}$ & 32 & 39 & 95 & 34 & 29 & 28 & 38 & 86 & 102 & 110 & 124 & 132 \\
\hline $\operatorname{Pr}$ & 3.32 & 4.01 & 9.29 & 3.68 & 3.03 & 2.93 & 4.08 & 10.1 & 13.7 & 12.7 & 15.0 & 15.9 \\
\hline $\mathrm{Nd}$ & 12.1 & 14.3 & 32 & 13.8 & 11.1 & 10.8 & 15.5 & 38 & 60 & 59 & 59 & 63 \\
\hline $\mathrm{Sm}$ & 2.06 & 2.31 & 4.47 & 2.46 & 1.88 & 1.91 & 2.70 & 6.85 & 10.8 & 10.7 & 10.8 & 11.5 \\
\hline $\mathrm{Eu}$ & 0.72 & 0.93 & 1.03 & 0.79 & 0.66 & 0.58 & 0.73 & 2.13 & 2.65 & 2.35 & 2.96 & 3.13 \\
\hline $\mathrm{Gd}$ & 2.11 & 2.34 & 4.44 & 2.49 & 1.96 & 2.00 & 2.79 & 7.26 & 9.51 & 9.08 & 10.9 & 11.5 \\
\hline $\mathrm{Tb}$ & 0.32 & 0.34 & 0.57 & 0.38 & 0.30 & 0.32 & 0.44 & 0.85 & 1.15 & 1.03 & 1.32 & 1.39 \\
\hline Dy & 1.77 & 1.82 & 2.86 & 2.21 & 1.71 & 1.86 & 2.51 & 4.47 & 5.55 & 5.47 & 6.73 & 7.09 \\
\hline Ho & 0.40 & 0.40 & 0.57 & 0.49 & 0.38 & 0.43 & 0.55 & 0.82 & 1.01 & 0.98 & 1.24 & 1.30 \\
\hline Er & 11.9 & 1.16 & 1.57 & 1.44 & 1.14 & 1.31 & 1.59 & 2.70 & 3.14 & 2.90 & 3.88 & 4.08 \\
\hline $\mathrm{Tm}$ & 0.20 & 0.20 & 0.26 & 0.25 & 0.19 & 0.23 & 0.27 & 0.36 & 0.40 & 0.38 & 0.51 & 0.54 \\
\hline $\mathrm{Yb}$ & 1.45 & 1.39 & 1.78 & 1.68 & 1.36 & 1.62 & 1.81 & 2.55 & 2.79 & 2.57 & 3.48 & 3.72 \\
\hline $\mathrm{Lu}$ & 0.23 & 0.22 & 0.28 & 0.26 & 0.22 & 0.26 & 0.27 & 0.37 & 0.40 & 0.36 & 0.50 & 0.53 \\
\hline $\mathrm{Y}$ & 11.4 & 11.4 & 15.4 & 13.8 & 11.0 & 12.7 & 15.1 & 23 & 27 & 26 & 33 & 35 \\
\hline $\mathrm{Nb}$ & 8.53 & 8.61 & 11.1 & 8.64 & 6.94 & 9.08 & 10.4 & 16.7 & 21 & 21 & 17 & 18 \\
\hline $\mathrm{Zr}$ & 140 & 145 & 99 & 140 & 118 & 115 & 170 & 284 & 249 & 242 & 232 & 252 \\
\hline $\mathrm{Hf}$ & 4.13 & 4.05 & 2.66 & 4.03 & 3.48 & 3.51 & 4.80 & 7.26 & 6.82 & 6.58 & 6.26 & 6.74 \\
\hline $\mathrm{Ta}$ & 0.58 & 0.53 & 1.02 & 0.66 & 0.51 & 0.64 & 0.75 & 0.96 & 1.26 & 1.10 & 1.42 & 1.44 \\
\hline Th & 21 & 6.86 & 27 & 13.1 & 6.44 & 13.4 & 8.55 & 23 & 46 & 39 & 15.4 & 15.1 \\
\hline REE & 75 & 91 & 209 & 82 & 68 & 67 & 92 & 208 & 262 & 267 & 302 & 319 \\
\hline $\mathrm{Eu} / \mathrm{Eu}^{*}$ & 1.06 & 1.22 & 0.71 & 0.98 & 1.06 & 0.90 & 0.81 & 0.92 & 0.80 & 0.73 & 0.83 & 0.83 \\
\hline
\end{tabular}


and Monastery ${ }^{176} \mathrm{Hf} /{ }^{177} \mathrm{Hf}$ isotopic ratio of $0.282723 \pm 0.000016$ (Liu et al. 2010), respectively.

\section{3.c. Sr-Nd isotopic determination}

The $\mathrm{Sr}-\mathrm{Nd}$ isotopic compositions of selected samples were determined using a Micromass Isoprobe Neptune Plus multi-collection ICP-MS equipped with nine Faraday cup collectors and eight ion counters at the State Key Laboratory of Isotope Geochemistry, Guangzhou Institute of Geochemistry, Chinese Academy of Sciences. The analytical procedures were similar to those described in Liang et al. (2003). Sr and rare Earth elements (REEs) were separated using standard cation exchange columns, and the Nd fraction was isolated from the other REEs using Di-(2ethylhexyl)phosphoric acid (HDEHP) columns. The normalizing factors used to correct the mass fractionation of $\mathrm{Sr}$ and $\mathrm{Nd}$ during the measurements were ${ }^{86} \mathrm{Sr} /{ }^{88} \mathrm{Sr}=0.1194$ and ${ }^{146} \mathrm{Nd} /{ }^{144} \mathrm{Nd}=0.7219$, respectively. The reported ${ }^{87} \mathrm{Sr} /{ }^{86} \mathrm{Sr}$ and ${ }^{143} \mathrm{Nd} /{ }^{144} \mathrm{Nd}$ ratios were adjusted to the NBS SRM 987 standard ${ }^{87} \mathrm{Sr} /{ }^{86} \mathrm{Sr}=0.71025$ and the Shin Etsu JNdi-1 standard ${ }^{143} \mathrm{Nd} /{ }^{144} \mathrm{Nd}=0.512115$, respectively.

\section{Results}

\section{4.a. Whole-rock geochemistry}

The whole-rock analyses of major and trace elements from all our samples are presented in Table 1. Previously published data (Jiang et al. 2002; Liao et al. 2010; Gao et al. 2013) for similar lithological assemblages from the Datong pluton are included for comparison. According to their $\mathrm{SiO}_{2}$ and alkali content, these samples can be categorized into monzodiorites, diorites, monzonites, quartz monzonites, syenites and monzogranites. In terms of the composition variation on the plutonic total alkali v. silica (TAS) diagram (Fig. 5), separate arrays extend from the monzodiorite towards the syenite or granite fields, analogous to the Northern Highland plutons of the British Caledonian Province as observed by Fowler et al. (2008). Moreover, all samples feature a high-K calc-alkaline to shoshonite composition on the $\mathrm{K}_{2} \mathrm{O}$ v. $\mathrm{SiO}_{2}$ diagram (Peccerillo \& Taylor, 1976; Fig. 6a). In this regard, such geochemical characteristics are akin to the fundamental properties that characterize the appinite suite of rocks (Castro et al. 2003; Fowler et al. 2008; Murphy, 2013). In addition, based on the classification scheme of Frost et al. (2001), most samples are of the magnesium type and plot within or very close to the typical Caledonian post-collisional pluton field (Fig. 6b). Among our samples, the four monzonites show $\mathrm{SiO}_{2}, \mathrm{Fe}_{2} \mathrm{O}_{3}{ }^{*}, \mathrm{MgO}$ and $\mathrm{CaO}$ contents of $56-58 \mathrm{wt} \%, 6.05-7.30 \mathrm{wt} \%, 3.85-4.55 \mathrm{wt} \%$ and $3.48-6.50 \mathrm{wt} \%$, respectively, with $\mathrm{Mg}$ no. values of 58-60 (Table 1, Fig. 6c). Their A/CNK (molecular $\left.\mathrm{Al}_{2} \mathrm{O}_{3} /\left(\mathrm{CaO}+\mathrm{Na}_{2} \mathrm{O}+\mathrm{K}_{2} \mathrm{O}\right)\right)$ values range over $0.65-0.98$, indicating a metaluminous nature (Maniar

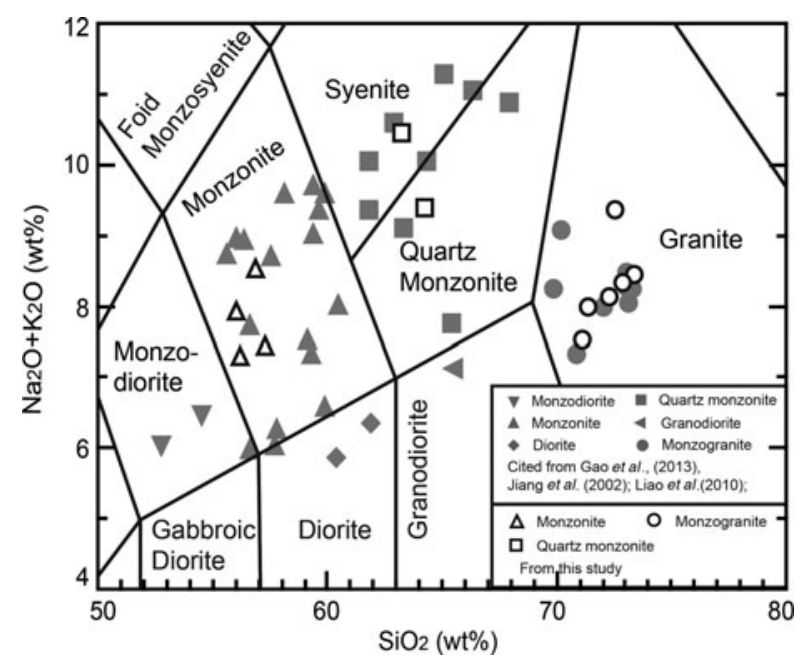

Figure 5. Total alkalis v. silica diagram (TAS, after Middlemost, 1994) showing petrochemical classification of the Datong pluton. Symbols for these samples are indicated within the inset. Solid symbols represent data from Jiang et al. (2002), Liao et al. (2010) and Gao et al. (2013).

\& Piccoli, 1989; Fig. 6d). In contrast, the six granites have higher $\mathrm{SiO}_{2}$ contents $(71-73 \mathrm{wt} \%)$, lower contents of $\mathrm{Fe}_{2} \mathrm{O}_{3}{ }^{*}(1.10-1.61 \mathrm{wt} \%), \mathrm{CaO}(0.53-$ $2.25 \mathrm{wt} \%), \mathrm{MgO}(0.17-0.48 \mathrm{wt} \%)$, and variable $\mathrm{Mg}$ no. values of $25-50$ (Table 1, Fig. 6c). Five of them are peraluminous $(\mathrm{A} / \mathrm{CNK}=1.09-1.21)$ and one of them is metaluminous $(\mathrm{A} / \mathrm{CNK}=0.99)$ (Fig. 6d). The remaining samples (two quartz monzonites) are marked by medium $\mathrm{SiO}_{2}$ contents (63-64 wt \%), moderate $\mathrm{Fe}_{2} \mathrm{O}_{3}{ }^{*}(1.72-3.38 \mathrm{wt} \%), \mathrm{CaO}(2.18-3.00 \mathrm{wt} \%)$ and $\mathrm{MgO}(0.98-1.30 \mathrm{wt} \%)$ contents, and moderate $\mathrm{Mg}$ no. values (47-57). These rocks plot in the metaluminous to peraluminous fields on the $\mathrm{A} / \mathrm{NK}$ versus $\mathrm{A} / \mathrm{CNK}$ diagram (Fig. 6d).

Across the whole spectrum of our sample compositions, the chondrite-normalized REE patterns are moderately fractionated. The $(\mathrm{La} / \mathrm{Yb})_{\mathrm{N}}$ ratios vary over 11.66-13.26 for monzonites, 7.48-11.95 for quartz monzonites and 6.07-20.74 for monzogranites (Table 1). The magnitude of the Eu anomaly (Eu/Eu* $\left.=\mathrm{Eu}_{\mathrm{N}} /\left(\mathrm{Sm}_{\mathrm{N}}{ }^{*} \mathrm{Gd}_{\mathrm{N}}\right)^{1 / 2}\right)$ varies over $0.71-1.22$ among all our samples. Moderately negative Eu anomalies, ranging over $0.73-0.83$, are present in the monzonites (Table 1). Based on all the available data, including the published data from Jiang et al. (2002) and Liao et al. (2010), the intermediate rocks have high REE contents with REE abundances systematically decreasing with the compositional transition to monzogranites, except for sample 12TS8-4 (Fig. 7). In the primitive mantle-normalized trace-element patterns (Fig. 7b, d, f), all the samples are relatively enriched in large-ion lithophile elements (LILEs) and REEs, with negative $\mathrm{Nb}, \mathrm{Ta}$ and $\mathrm{Ti}$ anomalies. The trace elements show slight variations between the different rock types. The monzonites exhibit negative $\mathrm{Ba}$ and $\mathrm{Sr}$ anomalies (Fig. 7b), whereas the others (quartz monzonites and monzogranites) display significant negative $\mathrm{P}$ and 

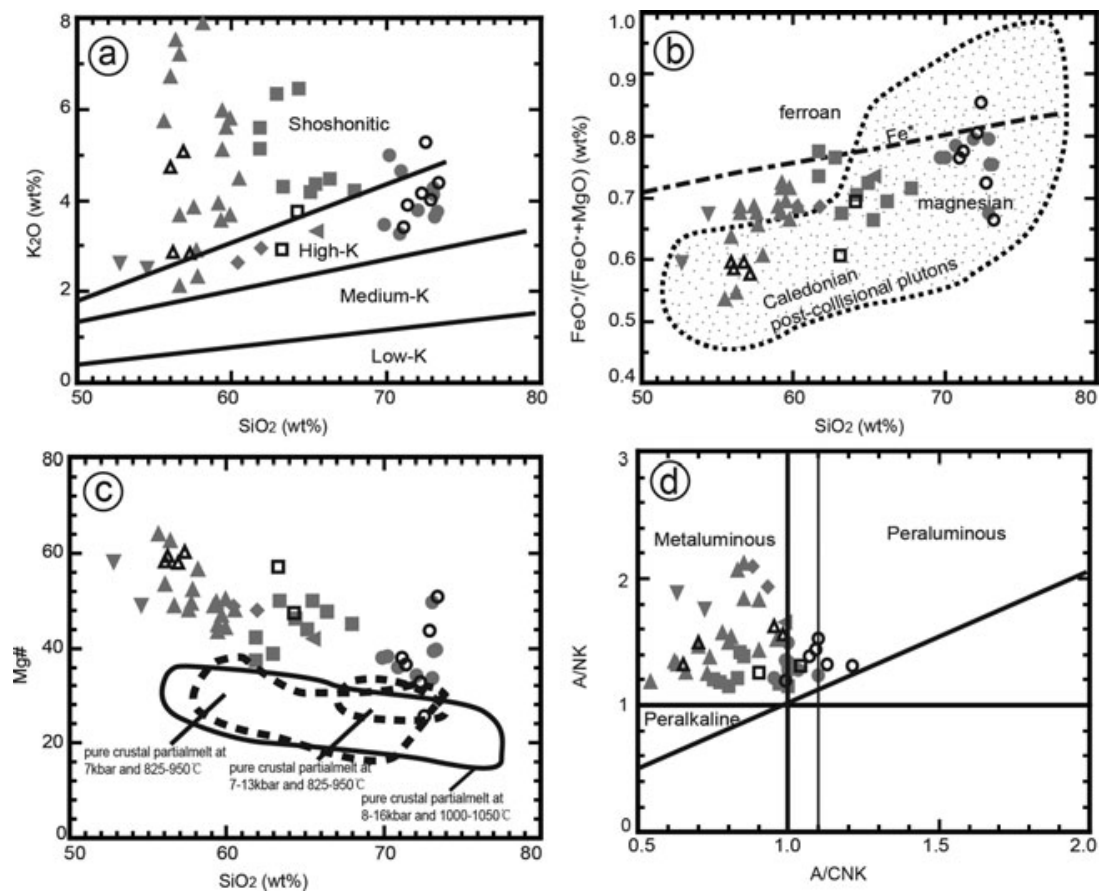

Figure 6. Geochemical characteristics for the major compositions. (a). $\mathrm{K}_{2} \mathrm{O}$ v. $\mathrm{SiO}_{2}$ classification diagram, after Peccerillo \& Taylor (1976); (b) $\mathrm{FeO}^{*} /\left(\mathrm{FeO}^{*}+\mathrm{MgO}\right)$ v. $\mathrm{SiO}_{2}$ diagram, after Frost et al. (2001); (c) $\mathrm{Mg}$ no. v. $\mathrm{SiO}_{2}$ diagram $(\mathrm{Mg}$ no. $=$ molar $\left.\mathrm{MgO} /\left(\mathrm{MgO}+0.85 \times \mathrm{FeO}^{*}\right)\right)$; the fields of pure crustal partial melts have been determined in experimental studies by dehydration melting of low-K basaltic rocks at $8-16 \mathrm{kbar}$ and $1000-1050{ }^{\circ} \mathrm{C}$ (Rapp \& Watson, 1995), pelitic rocks at 7-13 kbar and 825-950 ${ }^{\circ} \mathrm{C}($ Douce \& Johnston, 1991), and moderately hydrous $\left(1.7-2.3 \mathrm{wt} \% \mathrm{H}_{2} \mathrm{O}\right)$ medium- to high-K basaltic rocks at $7 \mathrm{kbar}$ and $825-950^{\circ} \mathrm{C}(\mathrm{Sisson}$ et al. 2005); and (d) A/NK (molar $\mathrm{Al}_{2} \mathrm{O}_{3} /\left(\mathrm{Na}_{2} \mathrm{O}+\mathrm{K}_{2} \mathrm{O}\right)$ ) v. $\mathrm{A} / \mathrm{CNK}$ (molar $\mathrm{Al}_{2} \mathrm{O}_{3} /\left(\mathrm{CaO}+\mathrm{Na}_{2} \mathrm{O}+\mathrm{K}_{2} \mathrm{O}\right)$ ) diagram, after $\mathrm{Maniar} \&$ Piccoli (1989). Symbols as for Figure 5.

small to pronounced $\mathrm{Ba}$ anomalies without $\mathrm{Sr}$ troughs (Fig. 7d, f).

\section{4.b. Zircon U-Pb-Hf isotopic systematics}

\section{4.b.1. Zircon $\mathrm{U}-\mathrm{Pb}$ isotopic dating results}

In the present study, we attempted to extract zircon grains from samples 12TS8-2, 13TSK04-2, 13TSK044 and 13TSK04-5. However, we were not able to obtain zircons from samples 13TSK04-2 and 13TSK044, which may be attributable to the suppression of zircon crystallization (Bea et al. 2006; Miller et al. 2007). For the Datong pluton, a $\mathrm{Zr}$ v. $\mathrm{SiO}_{2}$ plot (not shown) shows a convex-upwards array with a rough inflection at $60 \mathrm{wt} \%$, suggestive of the onset of zircon saturation (Watson \& Harrison, 1983; Miller et al. 2007). The results of the LA-ICP-MS zircon analyses are listed in Table 2. The U-Pb concordia diagrams and representative $C L$ images of the analysed zircon grains are shown in Figure 8. Zircons from samples 12TS8-2 and 13TSK04-5 have very similar morphological features, with aspect ratios of predominantly $2: 1$ to $3: 1$. The grain sizes do not differ substantially between these two petrographic types, mainly varying over the range $80-100 \mu \mathrm{m}$. The CL images show that most zones are euhedral and concentric, although some internal zones are truncated, indicating resorption and subsequent growth. The compositionally variable oscillatory zones (rims) that enclose oscillatory dark- light bands or homogenous euhedral-subhedral cores are visible. Notably, some zircons exhibit faint magmatic zoning from the interior to the exterior, indicative of a much simpler history of growth (Miller et al. 2007). The zircon $\mathrm{Th} / \mathrm{U}$ ratios range over $0.11-1.76$, signifying an igneous origin.

A total of 20 spots were analysed on 20 zircon grains from sample 13TSK04-5 (quartz monzonite), and all the spots showed low discordancy (less than $10 \%$ ) and are regarded as 'concordant'. The data are presented graphically in the concordia diagram in Figure $8 \mathrm{~b}$. With the exclusion of the two grains 10 and 12 with dates of $1366 \mathrm{Ma}\left({ }^{207} \mathrm{~Pb} /{ }^{206} \mathrm{~Pb}\right.$ age $)$ and $533 \mathrm{Ma}\left({ }^{206} \mathrm{~Pb} /{ }^{238} \mathrm{U}\right.$ age, Table 2$)$, respectively, which most likely represent the ages of zircon xenocrysts entrained by the magmatic intrusion (Fig. 8a), 18 spots yielded ${ }^{206} \mathrm{~Pb} /{ }^{238} \mathrm{U}$ apparent ages between $454 \pm 5$ and $470 \pm 5 \mathrm{Ma}$ and returned a weighted mean ${ }^{206} \mathrm{~Pb} /{ }^{238} \mathrm{U}$ age of $463 \pm 3 \mathrm{Ma}$, with an MSWD of $1.5(>1)$, implying a population that is not coherent (Wendt \& Carl, 1991). Moreover, these 18 analyses have uncertainties that overlap. However, the data display greater dispersion along the concordia (Fig. 8b), signifying that if lead loss can be discounted, those zircon grains could not have all crystallized contemporaneously despite their general similarity in age. The weighted mean ${ }^{206} \mathrm{~Pb} /{ }^{238} \mathrm{U}$ age of $463 \pm 3 \mathrm{Ma}$ must therefore be a statistically meaningless weighted mean age. An attempt was made to separate the age populations using statistical procedures, such as the mixture 

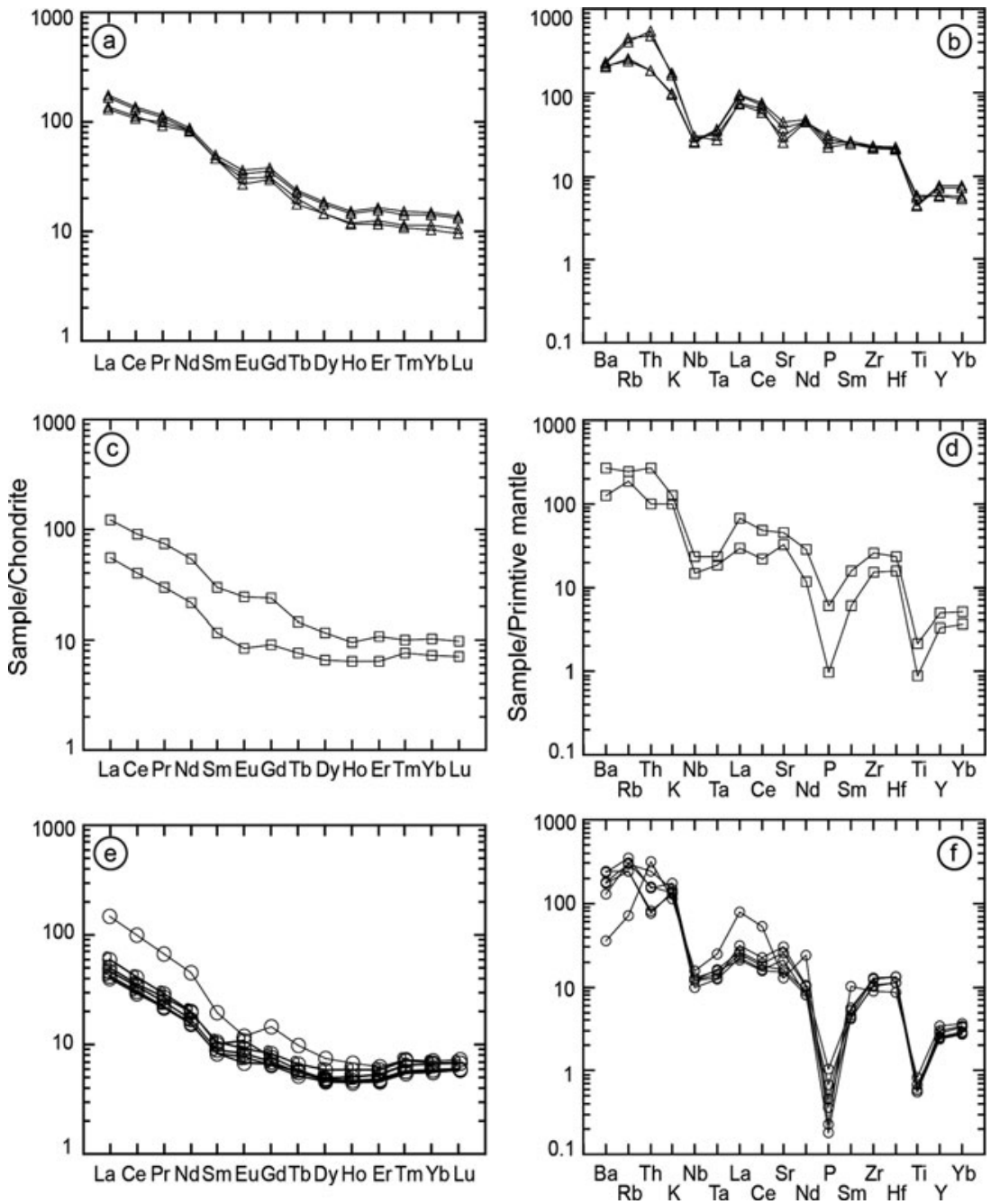

Figure 7. Chondrite-normalized REE patterns and primitive mantle-normalized spider diagrams for (a, b) monzonites; (c, d) quartz monzonites; and (e, f) monzogranites of the Datong pluton. Chondrite values are after Taylor \& McLennan (1985); primitive mantle values are after Sun \& McDonough (1989).

modelling approach (Sambridge \& Compston, 1994) and the 'cumulative Gaussian' curve with a half-width corresponding to $1 \sigma$ (Ludwig, 2003). However, this was not successful because of the large error of the individual ${ }^{206} \mathrm{~Pb} /{ }^{238} \mathrm{U}$ ages. According to the zircon $\mathrm{CL}$ images, analytical locations and the corresponding ages, the analyses can be categorized into two groups. The analyses from the tips of the zircons with core-rim textures and the zircons with simpler growth histories yield a statistically significant weighted mean ${ }^{206} \mathrm{~Pb} /{ }^{238} \mathrm{U}$ age of $459 \pm 3 \mathrm{Ma}(\mathrm{MSWD}=0.43$, Fig. $8 \mathrm{~b}$ ). This date represents our best estimate of the final crystallization of this sample. The remaining grains that are older (Table 2 ) define a weighted mean ${ }^{206} \mathrm{~Pb} /{ }^{238} \mathrm{U}$ age of $468 \pm 3 \mathrm{Ma}(\mathrm{MSWD}=0.1$, Fig. $8 \mathrm{~b}$ ) and apparently represent earlier crystal growth within the magmatic system, presumably being incorporated from slightly older and potentially still mushy parts of the magmatic system (Miller et al. 2007).

For sample 12TS8-2 (monzogranite), $19 \mathrm{U}-\mathrm{Pb}$ spot analyses were obtained on 19 zircon grains. All individual zircons yield concordant ages within error, but the ${ }^{206} \mathrm{~Pb} /{ }^{238} \mathrm{U}$ apparent ages range from $434 \pm 6 \mathrm{Ma}$ to $486 \pm 6 \mathrm{Ma}$ (Table 2), giving a weighted mean ${ }^{206} \mathrm{~Pb}^{238} \mathrm{U}$ age of $464 \pm 6 \mathrm{Ma}$ with an MSWD of 4.6 (> 2). Similar to sample 13TSK04-5, sample 12TS8-2 does not show consistent clustering (Fig. 8d), which must be attributable to real geological age variation. In fact, ${ }^{206} \mathrm{~Pb} /{ }^{238} \mathrm{U}$ apparent age variations are related to the morphological types and spot locations (Fig. 8c). In this sample, the apparent ages obtained are therefore distributed between two age populations (Fig. 8d). A set of 13 analyses with older ${ }^{206} \mathrm{~Pb} /{ }^{238} \mathrm{U}$ apparent ages (Fig. 8c) yields a weighted mean ${ }^{206} \mathrm{~Pb} /{ }^{238} \mathrm{U}$ age of $471 \pm 4 \mathrm{Ma}$ within analytical uncertainty $(\mathrm{MSWD}=0.97$ ). This appears to be the best estimate for the oldest zircon-forming event. The remaining six data points, except for one spot with a lower ${ }^{206} \mathrm{~Pb} /{ }^{238} \mathrm{U}$ apparent age $(434 \mathrm{Ma}$; Table 2) which may be attributable to $\mathrm{Pb}$ loss, represent the youngest concordant ages $(459 \pm 6 \mathrm{Ma}, 453 \pm 6 \mathrm{Ma}$, $452 \pm 6 \mathrm{Ma}$ and $445 \pm 6 \mathrm{Ma}$ ). Pooling these five analyses, this cluster defines a weighted mean ${ }^{206} \mathrm{~Pb} /{ }^{238} \mathrm{U}$ age of $452 \pm 5 \mathrm{Ma}$ with an MSWD of 0.69 , which probably represents the crystallization age of this sample. 
Table 2. Results of LA-ICP-MS U-Pb zircon dating for sample 13TSK04-5 and 12TS8-2 from the Datong pluton.

\begin{tabular}{|c|c|c|c|c|c|c|c|c|c|c|c|c|c|c|c|}
\hline \multirow[b]{2}{*}{ Spot } & \multirow[b]{2}{*}{ Th (ppm) } & \multirow[b]{2}{*}{$\mathrm{U}(\mathrm{ppm})$} & \multicolumn{7}{|c|}{ Isotopic ratios } & \multicolumn{6}{|c|}{ Apparent ages (Ma) } \\
\hline & & & $\mathrm{Th} / \mathrm{U}$ & ${ }^{207} \mathrm{~Pb} /{ }^{206} \mathrm{~Pb}$ & $1 \sigma$ & ${ }^{207} \mathrm{~Pb} /{ }^{235} \mathrm{U}$ & $1 \sigma$ & ${ }^{206} \mathrm{~Pb} /{ }^{238} \mathrm{U}$ & $1 \sigma$ & ${ }^{207} \mathrm{~Pb} /{ }^{206} \mathrm{~Pb}$ & $1 \sigma$ & ${ }^{207} \mathrm{~Pb} /{ }^{235} \mathrm{U}$ & $1 \sigma$ & ${ }^{206} \mathrm{~Pb} /{ }^{238} \mathrm{U}$ & $1 \sigma$ \\
\hline \multicolumn{16}{|c|}{ 13TSK04-5 Quartz Monzonite } \\
\hline 1 & 666 & 1109 & 0.60 & 0.0556 & 0.0020 & 0.5655 & 0.0194 & 0.0732 & 0.0007 & 435 & 84.3 & 455 & 12.6 & 456 & 4.5 \\
\hline 2 & 1369 & 1607 & 0.85 & 0.0577 & 0.0016 & 0.6018 & 0.0159 & 0.0749 & 0.0006 & 517 & 59.3 & 478 & 10.1 & 466 & 3.7 \\
\hline 3 & 1779 & 2140 & 0.83 & 0.0566 & 0.0016 & 0.5951 & 0.0164 & 0.0756 & 0.0009 & 476 & 93.5 & 474 & 10.4 & 470 & 5.3 \\
\hline 4 & 499 & 808 & 0.62 & 0.0558 & 0.0020 & 0.5838 & 0.0211 & 0.0754 & 0.0009 & 456 & 81.5 & 467 & 13.5 & 469 & 5.3 \\
\hline 5 & 688 & 1088 & 0.63 & 0.0551 & 0.0021 & 0.5593 & 0.0206 & 0.0729 & 0.0008 & 417 & 85.2 & 451 & 13.4 & 454 & 4.7 \\
\hline 6 & 1068 & 1503 & 0.71 & 0.0560 & 0.0020 & 0.5862 & 0.0201 & 0.0753 & 0.0008 & 454 & 79.6 & 468 & 12.8 & 468 & 5.0 \\
\hline 7 & 1698 & 1910 & 0.89 & 0.0558 & 0.0019 & 0.5689 & 0.0185 & 0.0735 & 0.0008 & 443 & 74.1 & 457 & 12.0 & 457 & 4.6 \\
\hline 8 & 2135 & 2462 & 0.87 & 0.0569 & 0.0016 & 0.5776 & 0.0156 & 0.0735 & 0.0007 & 487 & 56.5 & 463 & 10.0 & 457 & 4.4 \\
\hline 9 & 1419 & 1899 & 0.75 & 0.0592 & 0.0017 & 0.6129 & 0.0169 & 0.0744 & 0.0006 & 576 & 64.8 & 485 & 10.6 & 462 & 3.8 \\
\hline 10 & 520 & 1132 & 0.46 & 0.0872 & 0.0026 & 2.7076 & 0.1142 & 0.2148 & 0.0057 & 1366 & 56.0 & 1331 & 31.3 & 1254 & 30.3 \\
\hline 11 & 1051 & 1601 & 0.66 & 0.0539 & 0.0016 & 0.5557 & 0.0169 & 0.0742 & 0.0008 & 369 & 68.5 & 449 & 11.0 & 461 & 4.8 \\
\hline 12 & 3124 & 2709 & 1.15 & 0.0552 & 0.0014 & 0.6639 & 0.0222 & 0.0861 & 0.0018 & 420 & 57.4 & 517 & 13.5 & 533 & 10.5 \\
\hline 13 & 748 & 878 & 0.85 & 0.0578 & 0.0022 & 0.5890 & 0.0226 & 0.0736 & 0.0008 & 520 & 86.1 & 470 & 14.5 & 458 & 4.6 \\
\hline 14 & 1060 & 1535 & 0.69 & 0.0557 & 0.0016 & 0.5798 & 0.0175 & 0.0754 & 0.0008 & 443 & 66.7 & 464 & 11.2 & 469 & 4.8 \\
\hline 15 & 1014 & 1432 & 0.71 & 0.0560 & 0.0017 & 0.5797 & 0.0183 & 0.0753 & 0.0009 & 454 & 68.5 & 464 & 11.8 & 468 & 5.4 \\
\hline 16 & 2732 & 2886 & 0.95 & 0.0536 & 0.0014 & 0.5479 & 0.0150 & 0.0741 & 0.0007 & 354 & 56.5 & 444 & 9.8 & 461 & 3.9 \\
\hline 17 & 656 & 1061 & 0.62 & 0.0540 & 0.0016 & 0.5478 & 0.0164 & 0.0737 & 0.0007 & 372 & 68.5 & 444 & 10.8 & 458 & 4.2 \\
\hline 18 & 2555 & 2796 & 0.91 & 0.0524 & 0.0011 & 0.5461 & 0.0120 & 0.0753 & 0.0006 & 306 & 50.0 & 442 & 7.9 & 468 & 3.8 \\
\hline 19 & 1172 & 1566 & 0.75 & 0.0566 & 0.0014 & 0.5959 & 0.0162 & 0.0757 & 0.0008 & 476 & 55.6 & 475 & 10.3 & 470 & 4.9 \\
\hline 20 & 779 & 1193 & 0.65 & 0.0537 & 0.0015 & 0.5564 & 0.0156 & 0.0754 & 0.0007 & 367 & 60.2 & 449 & 10.2 & 468 & 4.5 \\
\hline \multicolumn{16}{|c|}{ 12TS8-2 Monzongranite } \\
\hline 1 & 1031 & 1030 & 1.00 & 0.05634 & 0.00077 & 0.57865 & 0.00794 & 0.0745 & 0.00100 & 465 & 30.2 & 464 & 5.1 & 463 & 6.0 \\
\hline 2 & 200 & 1882 & 0.11 & 0.05622 & 0.00076 & 0.57160 & 0.00774 & 0.0738 & 0.00099 & 460 & 29.8 & 459 & 5.0 & 459 & 5.9 \\
\hline 3 & 242 & 304 & 0.80 & 0.05623 & 0.00124 & 0.58529 & 0.01258 & 0.0755 & 0.00108 & 461 & 48.4 & 468 & 8.1 & 469 & 6.5 \\
\hline 4 & 509 & 618 & 0.82 & 0.05691 & 0.00096 & 0.59483 & 0.00994 & 0.0758 & 0.00105 & 487 & 37.3 & 474 & 6.3 & 471 & 6.3 \\
\hline 5 & 500 & 565 & 0.88 & 0.05599 & 0.00100 & 0.56228 & 0.00986 & 0.0728 & 0.00101 & 452 & 38.8 & 453 & 6.4 & 453 & 6.1 \\
\hline 6 & 1042 & 811 & 1.29 & 0.05435 & 0.00088 & 0.55865 & 0.00892 & 0.0746 & 0.00104 & 386 & 35.7 & 451 & 5.8 & 464 & 6.2 \\
\hline 7 & 607 & 815 & 0.75 & 0.05493 & 0.00083 & 0.57195 & 0.00858 & 0.0755 & 0.00104 & 410 & 33.1 & 459 & 5.6 & 469 & 6.3 \\
\hline 8 & 664 & 712 & 0.93 & 0.05557 & 0.00084 & 0.57754 & 0.00870 & 0.0754 & 0.00104 & 435 & 32.9 & 463 & 5.6 & 469 & 6.2 \\
\hline 9 & 1045 & 1073 & 0.97 & 0.05526 & 0.00076 & 0.55290 & 0.00766 & 0.0726 & 0.00099 & 422 & 30.3 & 447 & 5.0 & 452 & 6.0 \\
\hline 10 & 705 & 1567 & 0.45 & 0.05639 & 0.00068 & 0.58373 & 0.00721 & 0.0751 & 0.00102 & 467 & 26.8 & 467 & 4.6 & 467 & 6.1 \\
\hline 11 & 743 & 423 & 1.76 & 0.05662 & 0.00099 & 0.59380 & 0.01028 & 0.0761 & 0.00105 & 476 & 38.8 & 473 & 6.6 & 473 & 6.3 \\
\hline 12 & 1282 & 1630 & 0.79 & 0.05616 & 0.00076 & 0.55914 & 0.00759 & 0.0722 & 0.00097 & 459 & 29.4 & 451 & 4.9 & 450 & 5.8 \\
\hline 13 & 629 & 1314 & 0.48 & 0.05635 & 0.00089 & 0.54091 & 0.00845 & 0.0696 & 0.00095 & 466 & 34.8 & 439 & 5.6 & 434 & 5.7 \\
\hline 14 & 496 & 720 & 0.69 & 0.05752 & 0.00105 & 0.60352 & 0.01079 & 0.0761 & 0.00106 & 511 & 39.9 & 480 & 6.8 & 473 & 6.4 \\
\hline 15 & 294 & 483 & 0.61 & 0.05587 & 0.00089 & 0.55090 & 0.00868 & 0.0715 & 0.00099 & 447 & 34.5 & 446 & 5.7 & 445 & 6.0 \\
\hline 16 & 281 & 438 & 0.64 & 0.05742 & 0.00091 & 0.60020 & 0.00945 & 0.0758 & 0.00105 & 508 & 34.2 & 477 & 6.0 & 471 & 6.3 \\
\hline 17 & 559 & 887 & 0.63 & 0.05696 & 0.00079 & 0.61453 & 0.00856 & 0.0783 & 0.00107 & 489 & 30.7 & 486 & 5.4 & 486 & 6.4 \\
\hline 18 & 298 & 459 & 0.65 & 0.05590 & 0.00091 & 0.59177 & 0.00951 & 0.0768 & 0.00107 & 448 & 35.3 & 472 & 6.1 & 477 & 6.4 \\
\hline 19 & 903 & 905 & 1.00 & 0.05596 & 0.00085 & 0.59480 & 0.00901 & 0.0771 & 0.00107 & 450 & 33.2 & 474 & 5.7 & 479 & 6.4 \\
\hline
\end{tabular}



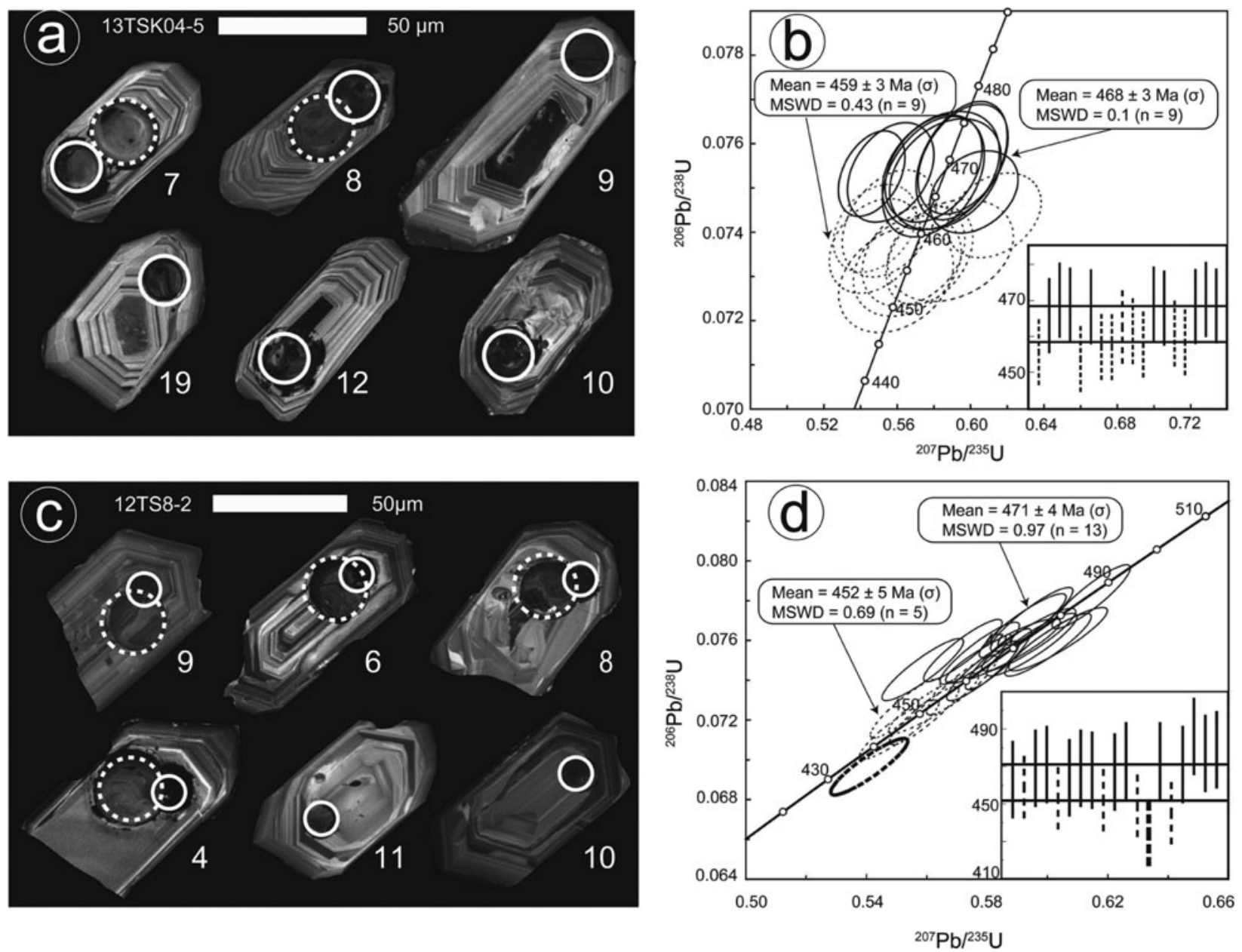

Figure 8. (a, c) CL images of representative zircon grains showing internal structures and analytical locations. Dashed circles are the analytical locations for $\mathrm{Hf}$ isotopic analyses; solid circles are the analytical locations for U- $\mathrm{Pb}$ dating. (b, d) U- $\mathrm{Pb}$ concordia diagrams and weighted mean ${ }^{206} \mathrm{~Pb} /{ }^{238} \mathrm{U}$ ages for samples 13 TSK04-5 and $12 \mathrm{TS} 8-2$. Dashed circles represent the younger ${ }^{206} \mathrm{~Pb} /{ }^{238} \mathrm{U}$ age population. Solid circles represent the older ${ }^{206} \mathrm{~Pb} /{ }^{238} \mathrm{U}$ age population. The bold dashed circle in (d) represents the age data excluded from the calculation.

\section{4.b.2. $L u-H$ f isotopes}

In situ $\mathrm{Lu}-\mathrm{Hf}$ isotopic analyses were obtained from the same spots as the LA-ICP-MS zircon U-Pb analyses, and the analytical results are listed in Table 3. In the analysis, eight analyses were obtained from zircons separated from sample 13TSK04-5, yielding ${ }^{176} \mathrm{Yb} /{ }^{177} \mathrm{Hf}$ and ${ }^{176} \mathrm{Hf} /{ }^{177} \mathrm{Hf}$ values of $0.00821-$ 0.04917 and $0.282455-0.282561$, respectively. Low ${ }^{176} \mathrm{Lu} /{ }^{177} \mathrm{Hf}$ values $(0.0004-0.0019)$ were also found, indicating a minor accumulation of radiogenic Hf. These analyses, corrected to the crystallization age $(\mathrm{t}=459 \mathrm{Ma})$, yield $\varepsilon_{\mathrm{Hf}}(\mathrm{t})$ values of -1.5 to 2.3 , singlestage $\mathrm{Hf}$ isotopic model $\left(\mathrm{T}_{\mathrm{DM}}\right)$ ages of $974-1139 \mathrm{Ma}$, and two-stage $\mathrm{Hf}$ isotopic model $\left(\mathrm{T}_{\mathrm{DM}}{ }^{\mathrm{C}}\right)$ ages of 1293-1539 Ma (Table 3). Another 10 analyses were performed on 10 dated zircon grains from sample 12TS8-2. These analyses show high ${ }^{176} \mathrm{Lu} /{ }^{177} \mathrm{Hf}$ ratios of $0.0004-0.0025$ and relatively consistent ${ }^{176} \mathrm{Hf} /{ }^{177} \mathrm{Hf}$ ratios of $0.282448-0.282638$. Corrected to the crystallization age $(\mathrm{t}=452 \mathrm{Ma})$, the calculated $\varepsilon_{\mathrm{Hf}}(\mathrm{t})$ values range from -1.6 to 4.7 , with $\mathrm{T}_{\mathrm{DM}}$ and $\mathrm{T}_{\mathrm{DM}}{ }^{\mathrm{C}}$ values of $885-1120 \mathrm{Ma}$ and $1136-1540 \mathrm{Ma}$, respectively (Table 3).

\section{4.c. $\mathrm{Sr}-\mathrm{Nd}$ isotopic compositions}

$\mathrm{Sr}-\mathrm{Nd}$ isotopic analyses were conducted on six samples of quartz monzonites and monzogranites collected from the Datong pluton. The $\mathrm{Sr}-\mathrm{Nd}$ isotopic compositions are presented in Table 4. The studied samples have ${ }^{87} \mathrm{Sr} /{ }^{86} \mathrm{Sr}$ and ${ }^{143} \mathrm{Nd} /{ }^{144} \mathrm{Nd}$ ratios of $0.715328-0.722463$ and $0.512115-0.512272$, respectively. The initial isotopic signatures are expressed as $\left({ }^{87} \mathrm{Sr} /{ }^{86} \mathrm{Sr}\right)_{\mathrm{i}}$ and $\varepsilon_{\mathrm{Nd}}(\mathrm{t})$, respectively. The data show a considerable range in the initial ${ }^{87} \mathrm{Sr} /{ }^{86} \mathrm{Sr}$ ratios from 0.7086 to 0.7185 . The $\varepsilon_{\mathrm{Nd}}(\mathrm{t})$ are characterized by negative values from -3.72 to -1.79 . Our data are consistent with those of previous isotopic studies on the rocks from enclaves, monzonite, quartz monzonite and monzogranites (Liao et al. 2010; Table 4). The $\mathrm{Sm}-\mathrm{Nd}$ model ages were calculated assuming a depleted mantle source, yielding Nd model ages of 1.21$1.36 \mathrm{Ga}$ (Table 4). The dataset, including our samples and published data from Liao et al. (2010), is plotted on the classical $\varepsilon_{\mathrm{Nd}}(\mathrm{t})$ v. $\left({ }^{87} \mathrm{Sr} /{ }^{86} \mathrm{Sr}\right)_{\mathrm{i}}$ diagram (Fig. 9). These data define a subhorizontal array and fall into the enriched quadrant within or near the lithospheric mantle array. 
Table 3. Lu-Hf isotopic data of zircons from the samples 12TS8-2 and 13TSK04-5 of the Datong pluton.

\begin{tabular}{|c|c|c|c|c|c|c|c|c|c|c|c|c|c|}
\hline Spot & Age (Ma) & ${ }^{176} \mathrm{Yb} /{ }^{177} \mathrm{Hf}$ & $1 \sigma$ & ${ }^{176} \mathrm{Lu} /{ }^{177} \mathrm{Hf}$ & $1 \sigma$ & ${ }^{176} \mathrm{Hf} /{ }^{177} \mathrm{Hf}$ & $1 \sigma$ & ${ }^{176} \mathrm{Hf} /{ }^{177} \mathrm{Hf}_{\mathrm{i}}$ & $\varepsilon_{\mathrm{Hf}}(0)$ & $\varepsilon_{\mathrm{Hf}}(\mathrm{t})$ & $\mathrm{T}_{\mathrm{DM}}(\mathrm{Ma})$ & $\mathrm{f}_{\mathrm{Lu} / \mathrm{Hf}}$ & $\mathrm{T}_{\mathrm{DM}}{ }^{\mathrm{C}}(\mathrm{Ma})$ \\
\hline \multicolumn{14}{|c|}{$12 \mathrm{TS} 8-2$} \\
\hline 1 & 452 & 0.03494 & 0.001714 & 0.0011 & 0.00005 & 0.282461 & 0.000007 & 0.282452 & -11.0 & -1.4 & 1120 & -0.97 & 1522 \\
\hline 2 & 452 & 0.07580 & 0.002525 & 0.0020 & 0.00006 & 0.282608 & 0.000008 & 0.282591 & -5.8 & 3.5 & 936 & -0.94 & 1210 \\
\hline 3 & 452 & 0.06818 & 0.001440 & 0.0016 & 0.00003 & 0.282638 & 0.000008 & 0.282624 & $\begin{array}{r}-4.8 \\
-4\end{array}$ & 4.7 & 885 & -0.95 & 1136 \\
\hline 4 & 452 & 0.06937 & 0.000844 & 0.0016 & 0.00001 & 0.282549 & 0.000010 & 0.282535 & -7.9 & 1.6 & 1011 & -0.95 & 1336 \\
\hline 5 & 452 & 0.01383 & 0.000155 & 0.0004 & 0.00000 & 0.282448 & 0.000008 & 0.282444 & -11.5 & -1.6 & 1120 & -0.99 & 1540 \\
\hline 6 & 452 & 0.05026 & 0.001219 & 0.0014 & 0.00003 & 0.282507 & 0.000009 & 0.282495 & -9.4 & 0.2 & 1065 & -0.96 & 1427 \\
\hline 7 & 452 & 0.02294 & 0.000175 & 0.0007 & 0.00000 & 0.282545 & 0.000008 & 0.282539 & -8.0 & 1.7 & 992 & -0.98 & 1326 \\
\hline 8 & 452 & 0.04377 & 0.002160 & 0.0013 & 0.00006 & 0.282512 & 0.000008 & 0.282501 & -9.2 & 0.4 & 1055 & -0.96 & 1413 \\
\hline 9 & 452 & 0.05221 & 0.000890 & 0.0016 & 0.00003 & 0.282499 & 0.000006 & 0.282485 & -9.7 & -0.2 & 1082 & -0.95 & 1448 \\
\hline 10 & 452 & 0.08954 & 0.001235 & 0.0025 & 0.00003 & 0.282506 & 0.000009 & 0.282485 & -9.4 & -0.2 & 1099 & -0.92 & 1449 \\
\hline \multicolumn{14}{|c|}{ 13TSK04-5 } \\
\hline 1 & 459 & 0.00821 & 0.000300 & 0.0004 & 0.00001 & 0.282531 & 0.000012 & 0.282528 & -8.5 & 1.5 & 1004 & -0.99 & 1349 \\
\hline 2 & 459 & 0.01893 & 0.000524 & 0.0009 & 0.00002 & 0.282555 & 0.000010 & 0.282547 & -7.7 & 2.2 & 983 & -0.97 & 1304 \\
\hline 3 & 459 & 0.04917 & 0.003510 & 0.0019 & 0.00012 & 0.282554 & 0.000012 & 0.282538 & -7.7 & 1.8 & 1012 & -0.94 & 1326 \\
\hline 4 & 459 & 0.01501 & 0.000198 & 0.0007 & 0.00001 & 0.282559 & 0.000011 & 0.282552 & -7.5 & 2.3 & 974 & -0.98 & 1293 \\
\hline 5 & 459 & 0.00935 & 0.000164 & 0.0005 & 0.00001 & 0.282522 & 0.000008 & 0.282519 & -8.8 & 1.1 & 1017 & -0.99 & 1369 \\
\hline 6 & 459 & 0.02468 & 0.001718 & 0.0012 & 0.00009 & 0.282524 & 0.000009 & 0.282513 & $\begin{array}{l}-0.0 \\
-8.8\end{array}$ & 1.0 & 1036 & -0.96 & 1381 \\
\hline 7 & 459 & 0.02508 & 0.002345 & 0.0012 & 0.00010 & 0.282561 & 0.000009 & 0.282550 & -7.5 & 2.3 & 984 & -0.96 & 1297 \\
\hline 8 & 459 & 0.03257 & 0.000834 & 0.0014 & 0.00003 & 0.282455 & 0.000009 & 0.282443 & -11.2 & -1.5 & 1139 & -0.96 & 1539 \\
\hline
\end{tabular}

Note: $\varepsilon_{\mathrm{Hf}}(0)=\left[\left({ }^{176} \mathrm{Hf} /{ }^{177} \mathrm{Hf}\right)_{\mathrm{s}} /\left({ }^{176} \mathrm{Hf} /{ }^{177} \mathrm{Hf}\right)_{\mathrm{CHUR}}-1\right] \times 10000 ; \varepsilon_{\mathrm{Hf}}(\mathrm{t})=\left\{\left[\left({ }^{176} \mathrm{Hf} /{ }^{177} \mathrm{Hf}\right)_{\mathrm{s}}-\left({ }^{176} \mathrm{Lu} /{ }^{177} \mathrm{Hf}\right)_{\mathrm{s}} \times\left(\mathrm{e}^{\lambda \mathrm{t}}-1\right)\right] /\left[\left({ }^{176} \mathrm{Hf} /{ }^{177} \mathrm{Hf}\right)_{\mathrm{CHUR}}-\left({ }^{176} \mathrm{Lu} /{ }^{177} \mathrm{Hf}\right)_{\mathrm{CHUR}} \times\left(\mathrm{e}^{\lambda \mathrm{t}}-1\right)\right]-1\right\} \times 10000$;

$\mathrm{T}_{\mathrm{DM}}=1 / \lambda \times \ln \left\{1+\left[\left({ }^{176} \mathrm{Hf} /{ }^{177} \mathrm{Hf}\right)_{\mathrm{s}}-\left({ }^{176} \mathrm{Hf} /{ }^{177} \mathrm{Hf}\right)_{\mathrm{DM}}\right] /\left[\left({ }^{176} \mathrm{Lu} /{ }^{177} \mathrm{Hf}\right)_{\mathrm{s}}-\left({ }^{176} \mathrm{Lu} /{ }^{177} \mathrm{Hf}\right)_{\mathrm{DM}}\right]\right\} ; \mathrm{T}_{\mathrm{DM}} \mathrm{C}^{\mathrm{C}}=\mathrm{T}_{\mathrm{DM}}-\left(\mathrm{T}_{\mathrm{DM}}-\mathrm{t}\right) \times\left(f_{\mathrm{cc}}-f_{\mathrm{s}}\right) \times\left(f_{\mathrm{cc}}-f_{\mathrm{DM}}\right) ; f_{\mathrm{Lu} / \mathrm{Hf}}=\left[\left({ }^{176} \mathrm{Lu} /{ }^{177} \mathrm{Hf}\right)_{\mathrm{s}} /\left({ }^{176} \mathrm{Lu} /{ }^{177} \mathrm{Hf}\right)_{\mathrm{CHUR}}\right]-1 ;$

where $\left({ }^{176} \mathrm{Hf} /{ }^{177} \mathrm{Hf}\right)_{\mathrm{s}}$ and $\left({ }^{176} \mathrm{Lu} /{ }^{177} \mathrm{Hf}\right)_{\mathrm{s}}$ are measured values of samples; $\mathrm{s}-$ sample, $\mathrm{t}$ - crystallization time of zircon; $\left({ }^{176} \mathrm{Lu} /{ }^{177} \mathrm{Hf}\right)_{\mathrm{CHUR}}=0.0332 \mathrm{and}\left({ }^{176} \mathrm{Hf} /{ }^{177} \mathrm{Hf}\right)_{\mathrm{CHUR}}=0.282772(\mathrm{Blichert}-\mathrm{Toft} \&$ Albarède 1997); $\left({ }^{176} \mathrm{Lu} /{ }^{177} \mathrm{Hf}\right)_{\mathrm{DM}}=0.0384$ and $\left({ }^{176} \mathrm{Hf} /{ }^{177} \mathrm{Hf}\right)_{\mathrm{DM}}=0.28325$ (Griffin et al. 2000$) ; f_{\mathrm{cc}}=-0.55$ and $f_{\mathrm{DM}}=0.16 ; \lambda=1.867 \times 10^{-12} \mathrm{a}^{-1}$ (Söderlund et al. 2004 ) was used in the calculation. 

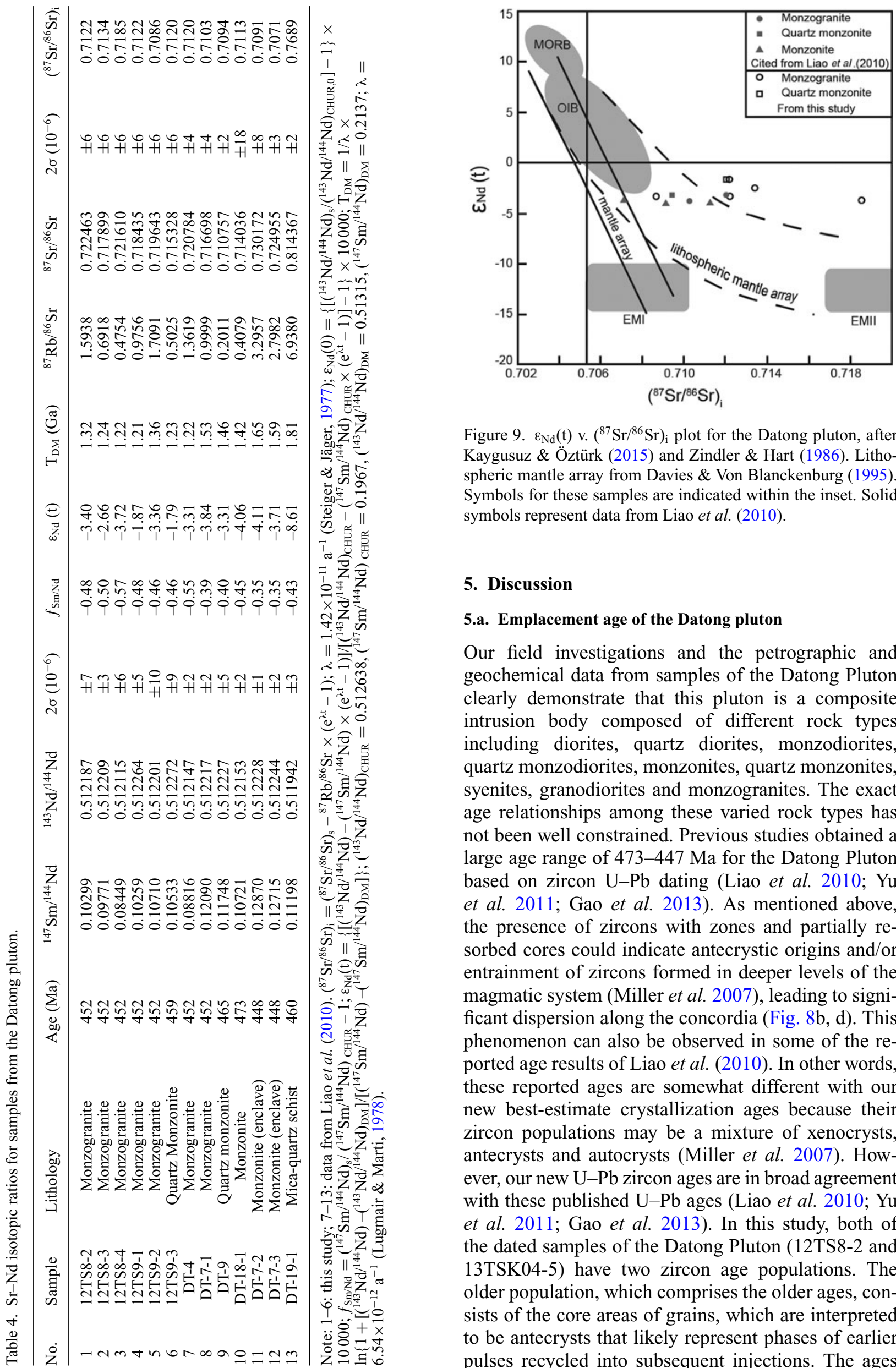

Figure 9. $\varepsilon_{\mathrm{Nd}}(\mathrm{t})$ v. $\left({ }^{87} \mathrm{Sr} /{ }^{86} \mathrm{Sr}\right)_{\mathrm{i}}$ plot for the Datong pluton, after Kaygusuz \& Öztürk (2015) and Zindler \& Hart (1986). Lithospheric mantle array from Davies \& Von Blanckenburg (1995). Symbols for these samples are indicated within the inset. Solid symbols represent data from Liao et al. (2010).

\section{Discussion}

\section{5.a. Emplacement age of the Datong pluton}

Our field investigations and the petrographic and geochemical data from samples of the Datong Pluton clearly demonstrate that this pluton is a composite intrusion body composed of different rock types including diorites, quartz diorites, monzodiorites, quartz monzodiorites, monzonites, quartz monzonites, syenites, granodiorites and monzogranites. The exact age relationships among these varied rock types has not been well constrained. Previous studies obtained a large age range of 473-447 Ma for the Datong Pluton based on zircon U-Pb dating (Liao et al. 2010; Yu et al. 2011; Gao et al. 2013). As mentioned above, the presence of zircons with zones and partially resorbed cores could indicate antecrystic origins and/or entrainment of zircons formed in deeper levels of the magmatic system (Miller et al. 2007), leading to significant dispersion along the concordia (Fig. 8b, d). This phenomenon can also be observed in some of the reported age results of Liao et al. (2010). In other words, these reported ages are somewhat different with our new best-estimate crystallization ages because their zircon populations may be a mixture of xenocrysts, antecrysts and autocrysts (Miller et al. 2007). However, our new $\mathrm{U}-\mathrm{Pb}$ zircon ages are in broad agreement with these published U-Pb ages (Liao et al. 2010; Yu et al. 2011; Gao et al. 2013). In this study, both of the dated samples of the Datong Pluton (12TS8-2 and 13TSK04-5) have two zircon age populations. The older population, which comprises the older ages, consists of the core areas of grains, which are interpreted to be antecrysts that likely represent phases of earlier pulses recycled into subsequent injections. The ages 
of the younger sets of analyses, which are mainly from the rims around older magmatic zircon cores (crystal growth) in samples 12TS8-2 and 13TSK04-5 or zircons with simpler growth histories, termed autocrysts, represent the best estimate for the crystallization of the Datong pluton. Furthermore, this younger age population (459-452 Ma) is indistinguishable from a reported SHRIMP $\mathrm{U}-\mathrm{Pb}$ zircon age population from a monzogranite (sample DT-7-1, 454 $\pm 5 \mathrm{Ma}$ ) within the Datong Pluton (Liao et al. 2010). The younger age population (459-452 Ma) therefore likely represents the main zircon crystallization phase in the Datong pluton. Furthermore, minor amounts of mafic magma were injected intermittently, forming mafic enclaves, which were dated with the SHRIMP $\mathrm{U}-\mathrm{Pb}$ zircon technique (sample DT-7-2, $448 \pm 5 \mathrm{Ma}$ ) by Liao et al. (2010). However, no geochronologic data are available for the mafic compositions, and it is not clear whether all compositions in the Datong share the same crystallization timing. The intrusive contacts and relationships among these rock types and the petrogenesis discussed below suggest that they crystallized at approximately the same time. The main body of the Datong pluton therefore formed at c. 459-448 Ma. In addition, some xenocryst zircons with Palaeozoic and Proterozoic ages (Table 2) indicate that magma genesis possibly incorporated material from the country rocks during transit and emplacement.

\section{5.b. Petrogenesis of the Datong pluton}

\section{5.b.1. Fractional crystallization and wall-rock assimilation}

As addressed above, the field, petrographic and geochemical observations provide substantive evidence of co-genetic origin among the rocks, particularly the intermediate and felsic compositions, of the Datong pluton. The main body of the intrusion is typified by monzodiorites, quartz monzodiorites, monzonites and quartz monzonites, while subsidiary units are felsic in composition, including syenites, granodiorites and monzogranites. According to the major- and traceelement compositions and isotope values, fractional crystallization was probably the main process driving differentiation, as discussed below. However, mafic microgranular enclaves are found occasionally in the Datong pluton and syn-plutonic mafic dykes are absent, suggesting that magma mixing and mafic recharge may have played some role in the petrogenesis of the Datong pluton although they are unlikely to have been a major factor. In fact, magma mixing should generate mixing curves in isotopic correlation diagrams (Fig. 9) and in plots between isotopic ratios and parameters, such as $\mathrm{SiO}_{2}$ (Fig. 10). These features are not observed in the Datong pluton, further indicating that magma mixing might not have been the dominant process during pluton formation. Additionally, although fractional crystallization may be considered to be the dominant process in

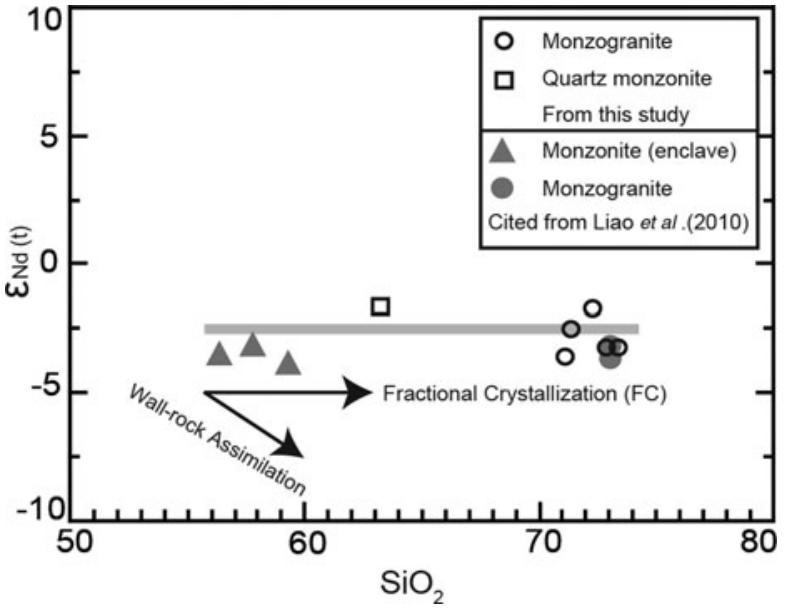

Figure 10. $\varepsilon_{\mathrm{Nd}}(\mathrm{t})$ v. $\mathrm{SiO}_{2}$ diagram.

the Datong pluton magmatic evolution, wall-rock assimilation of the surrounding wall rocks may also have been involved in its petrogenesis. Consequently, the geochemical variation and rock diversity in the Datong pluton cannot be accounted for by simple fractional crystallization of magma but can be explained by fractional crystallization coupled with wall-rock assimilation. We therefore first examine the role of crystal fractionation and then the possible effects of wall-rock assimilation.

Notably, the rocks from the Datong pluton have a wide range of silica contents (Fig. 5). The petrographic determinations reveal that the Datong pluton samples are composed of quartz + alkali feldspar + plagioclase + amphibole + biotite, titanite, apatite and opaque minerals. In the Harker diagrams (Fig. 11), all the data exhibit a curvilinear trend. Most major oxide variations display well-defined negative correlations with increasing $\mathrm{SiO}_{2}$ contents, reflecting the pronounced role of the progressive removal of different mineral species during the magmatic evolution from low- to high- $\mathrm{SiO}_{2}$ rocks in the Datong pluton. For example, the trends of decreasing $\mathrm{MgO}, \mathrm{MnO}, \mathrm{TiO}_{2}$, $\mathrm{CaO}$ and $\mathrm{Fe}_{2} \mathrm{O}_{3}{ }^{*}$ contents with increasing silica content are consistent with the fractionation of mafic minerals, such as biotite, clinopyroxene and hornblende. The negative correlation between $\mathrm{Y}$ and $\mathrm{SiO}_{2}$ (Fig. 12a) may be explained by the fractionation of hornblende. It is generally acknowledged that hornblende has higher distribution coefficients for middle REEs (MREEs, $\mathrm{Gd}$ to Ho) than for light and heavy REEs (Bachmann, Dungan \& Bussy, 2005; Prowatke \& Klemme, 2005; Imaoka et al. 2014). Hornblende fractionation is therefore able to produce REE patterns that are concave upwards with depleted MREEs in the residual liquids. Imaoka et al. (2014) recognized that the REE partition coefficient patterns of titanite (Bachmann, Dungan \& Bussy, 2005) and apatite (Sawka, 1988) are very similar to those of hornblende, but the values of the partition coefficients, especially in titanite, are greater than those of hornblende. Indeed, the REE 

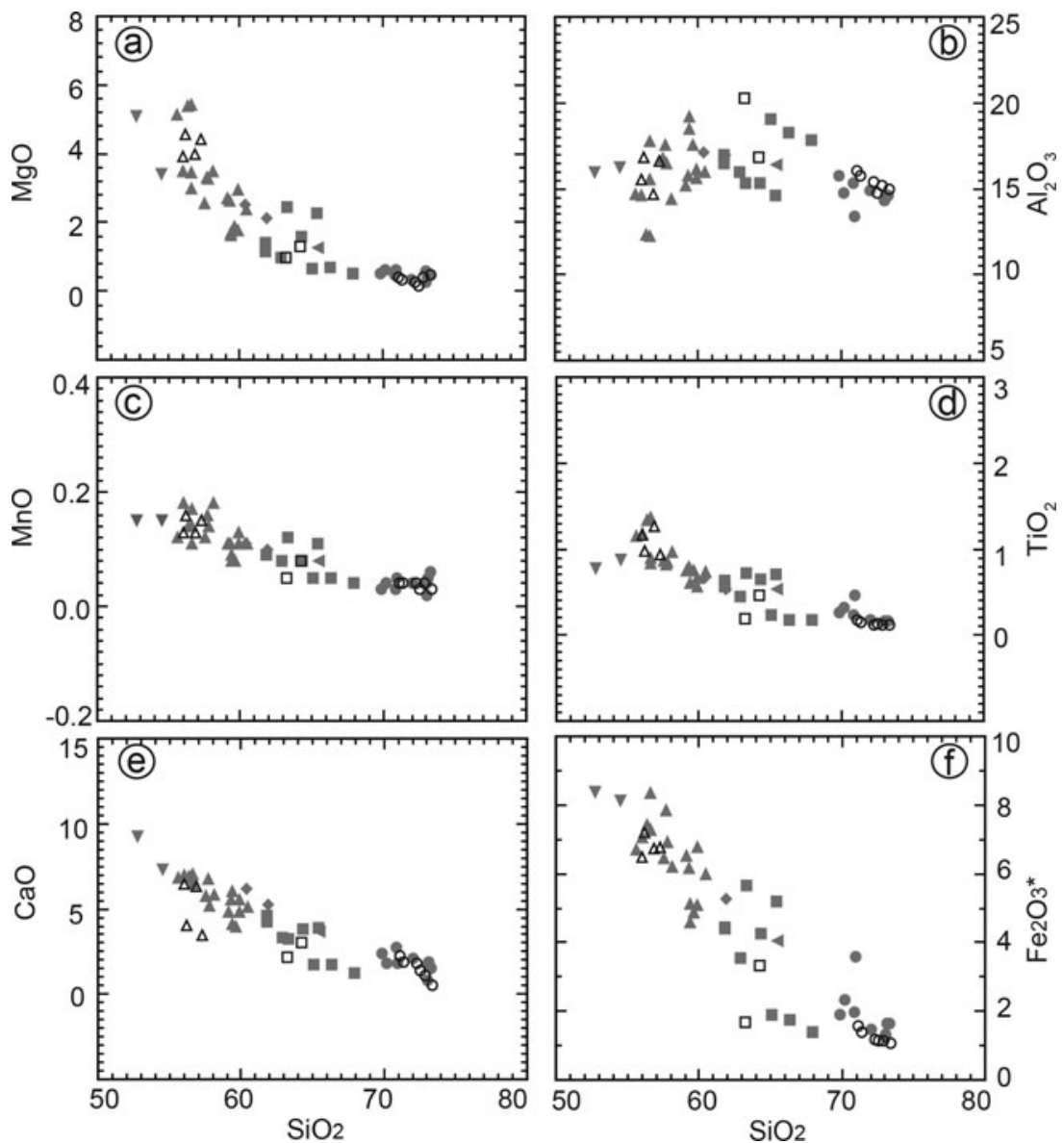

Figure 11. Harker diagrams for major-element oxide data. Symbols as for Figure 5.

patterns with REE abundances that systematically decrease from monzonites through quartz monzonites to monzogranites are in accordance with the removal of abundant REE-rich accessory phases, such as titanite, apatite and zircon, which are important accessory minerals in the Datong rocks. More importantly, on the primitive mantle-normalized multi-element diagrams (Fig. 7b, d, f), in terms of all these elements, the monzonite samples plot above the quartz monzonite and monzogranite samples and have subparallel patterns that lack only the troughs at $\mathrm{P}$ and Ti. These patterns can be interpreted as the result of apatite and titanite fractionation (Fowler et al. 2008). The relationship between $\mathrm{Sm}$ and $\mathrm{P}_{2} \mathrm{O}_{5}$ (Fig. 12b) further supports the interpretation of apatite separation from the magma (Fowler et al. 2001).

A conspicuous feature of this study is the convexupwards array for $\mathrm{Al}_{2} \mathrm{O}_{3}$ v. $\mathrm{SiO}_{2}$ (Fig. 11b), with a broad inflection at c. $60 \mathrm{wt} \% \mathrm{SiO}_{2}$, reflecting a change in liquid mineralogy. This pattern may be due to feldspar fractionation during quartz monzonite and monzogranite formation. The $\mathrm{Ba}-\mathrm{SiO}_{2}$ relationships provide information on feldspar and biotite fractionation (Fig. 12c). However, prominent negative Eu anomalies are not observed. This situation can be the result of the countervailing effects of the co-fractionation of hornblendes, apatites and titanites with negative
Eu anomalies (Sawka, 1988; Bachmann, Dungan \& Bussy, 2005; Imaoka et al. 2014). In this way, slightly negative and positive anomalies $\left(\mathrm{Eu} / \mathrm{Eu}^{*}=0.71-1.22\right)$ were produced, depending on the balance of the fractionated mineral assemblages in these rocks (Fig. 7). Additionally, Ba concentrations decrease with decreasing Sr contents (Fig. 12d), favouring the control of the crystal fractionation of biotite.

The Datong pluton rocks are characterized by 'crust-like' trace-element and isotopic signatures, such as enrichment in LILEs and light REEs, depletion in the high-field-strength elements (HFSEs) (Fig. 7) and enriched $\mathrm{Sr}-\mathrm{Nd}$ isotopic compositions (Fig. 9). These might imply either wall-rock assimilation or mantle metasomatism. Because the intrusion intruded into Proterozoic metamorphic basement and early Palaeozoic strata, and has some metasedimentary rafts of Proterozoic and early Palaeozoic age, contamination by sedimentary rocks seems inevitable. The presence of zircon xenocrysts in sample 13TSK04-5 raises the possibility that crustal components were incorporated into the Palaeozoic Datong magmatism. The relatively higher initial $\mathrm{Sr}$ isotopic values accompanied by broad variation (Table 4) could indicate the incorporation of differing amounts of crustal components. However, in terms of trace elements, the Datong rocks have much higher Sr (274-1250 ppm) than that 

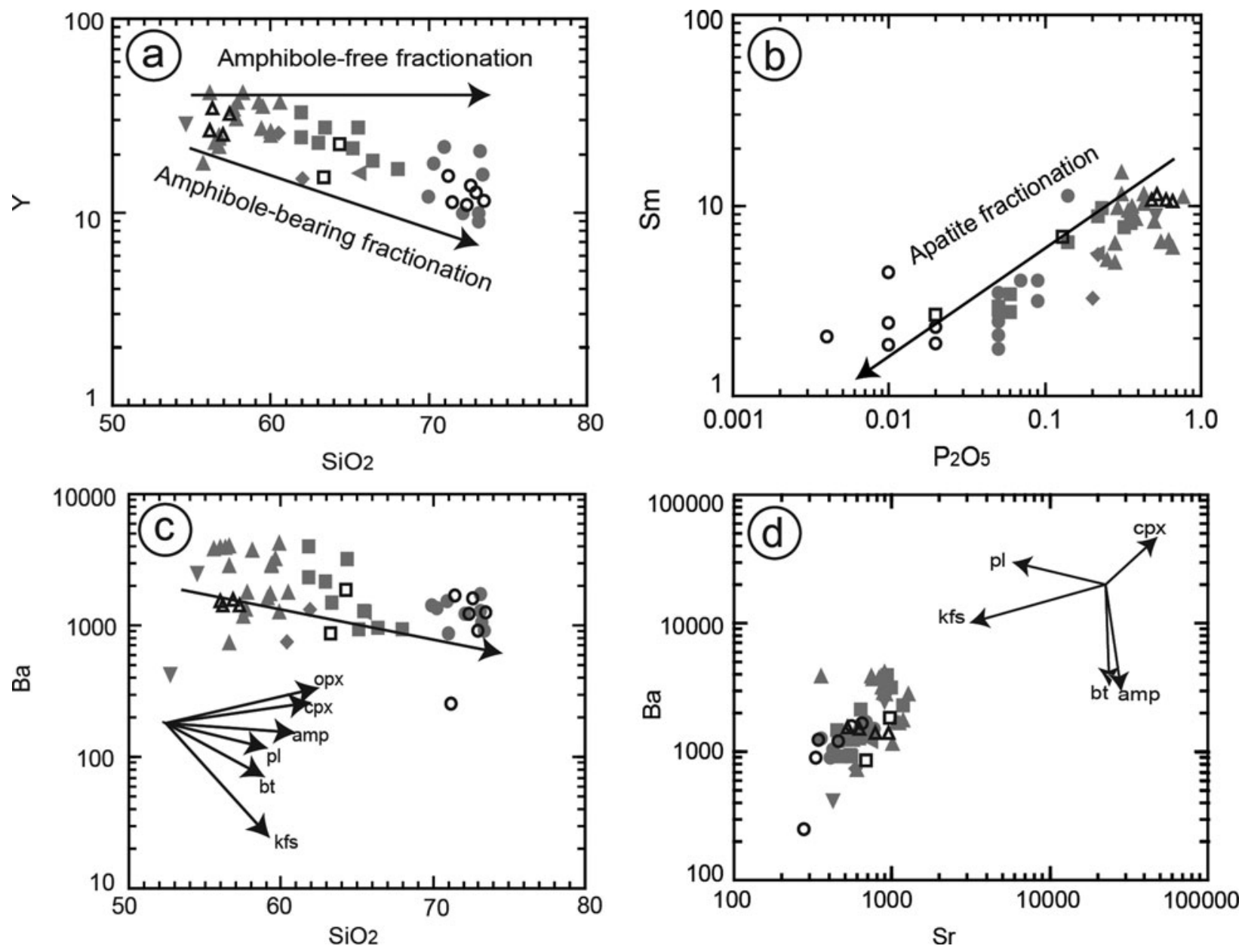

Figure 12. Fractionation vectors modelled for crystallization of individual mineral phases. (a) $\mathrm{Y} \mathrm{v}$. $\mathrm{SiO}_{2}$, showing a negative correlation that suggests amphibole-related fractionation, after Boztug et al. (2007). (b) Clear correlations of Sm with $\mathrm{P}_{2} \mathrm{O}_{5}$ suggest the fractionation of apatite, after Fowler et al. (2001). (c) $\mathrm{Ba}$ v. $\mathrm{SiO}_{2}$ diagram revealing feldspar and biotite fractionation, after Boztug et al. (2007). (d) Sr v. Ba revealing dominant biotite fractionation, after Fowler et al. (2008). Mineral abbreviations are after Whitney \& Evans (2010). Symbols as for Figure 5.

of the metamorphic basement country rocks (93 ppm), as represented by a Palaeoproterozoic mica-quartz schist (Liao et al. 2010). These patterns suggest that the Datong pluton might have experienced minor wall-rock assimilation. Furthermore, a very restricted range of $\mathrm{Nd}$ isotopic compositions over a wide range of $\mathrm{SiO}_{2}$ concentrations, coupled with a lack of a compositional trend towards the Precambrian metamorphic rocks, in the Datong rocks is inconsistent with the pattern commonly expected in simple cases of progressive wall-rock assimilation (Fig. 10). This case was also observed by Liao et al. (2010). Consequently, wall-rock assimilation does not appear to have been an important factor affecting the magma compositions.

In conclusion, the similar isotope and trace-element signatures for the rock types in the Datong pluton suggest a genetic linkage. The rock types in the Datong pluton were likely derived from a similar source, and the present compositional differences may be the result of fractional crystallization without predominant wall-rock assimilation.

\section{5.b.2. Magma generation and the nature of the mantle source}

The consistent geochemical and $\mathrm{Sr}-\mathrm{Nd}-\mathrm{Hf}$ isotopic compositions suggest that the monzonites, quartz monzonites and monzogranites in the Datong pluton were derived from the similar parental magma. The Datong samples exhibit high-K calc-alkaline to shoshonitic affinities in terms of major-element composition and feature abundant hydrous minerals (dominantly hornblendes and subordinate biotites). This association constitutes an appinite-granite complex. Investigations of appinitic rocks worldwide have demonstrated that most are of mantle origin with little or no crustal contribution (Fowler et al. 2008; Murphy, 2013), excluding a few cases such as the felsic rocks in the Greendale complex (Murphy, Hynes \& Cousens, 1997), which were generated by crustal anatexis (Castro et al. 2003) or magma mixing (Ye et al. 2008). The felsic-composition rocks in the appinitic suite generated from crustal sources were usually characterized by a 'chemical composition gap' between granites and appinites among major and trace elements (Rapp, Xiao \& Shimizu, 2002; MacPherson, 
Dreher \& Thirlwall, 2006; Ye et al. 2008) and a significantly lower $\varepsilon_{\mathrm{Nd}}(\mathrm{t})$ than mafic compositions rocks (Castro et al. 2003; Chen et al. 2004; Ye et al. 2008), which are discrepant from our Datong data. The view of cognation among the Datong rocks, particularly the intermediate and felsic rocks, is therefore further supported by this argument.

The Datong rocks have $\mathrm{Mg}$ no. values that are higher than expected for melts derived from metabasalts (Fig. 6c; Rapp \& Watson, 1995). The parental melts therefore originated from the mantle or via magma mixing between mantle-derived mafic and crust-derived silicic magmas. However, as addressed above, magma mixing is not the main process responsible for petrogenesis in these rocks. Partial melting of metasomatized subcontinental lithospheric mantle is widely regarded as the most likely process explaining the origin of the mafic component in appinitic rocks (Murphy, 2013). Indeed, the Sr and Nd isotopic compositions of the investigated samples do not fall into the fields for oceanic basalts (mid-ocean-ridge basalt (MORB) and ocean-island basalt (OIB)) and instead plot within or near the lithospheric mantle array (Fig. 9). This behaviour argues for their derivation from enriched subcontinental lithospheric mantle rather than asthenospheric or mantle plume sources. The Datong rocks belong to the high-K calc-alkaline to shoshonitic series and are characterized by enrichments of LREEs and LILEs and depletions of HFSEs, implying an origin from lithospheric mantle that had been metasomatized by subduction-related processes. This argument is also supported by the $\mathrm{Nb} / \mathrm{La}$ ratios of the studied rocks, which vary from 0.20 to 0.63 . These ratios are consistent with a lithospheric mantle source $(<0.5)$ but not an OIB-like asthenospheric mantle source $(>1)$ because HFSEs (such as $\mathrm{Nb}$ ad $\mathrm{Ta}$ ) are depleted in the lithospheric mantle relative to LREEs (Smith et al. 1999). Notably, in the primitive mantle-normalized spidergrams (Fig. 7), these rocks show both a depletion of $\mathrm{Nb}, \mathrm{Ta}$ and $\mathrm{Ti}$ and an enrichment of $\mathrm{Zr}$ and Hf. These features can be attributed to a mantle source rather than the result of a residue or fractional fractionation of either rutile or titanite; the residue or fractional fractionation of rutile or titanite would not only yield negative $\mathrm{Nb}, \mathrm{Ta}$, and $\mathrm{Ti}$ anomalies, but would also lead to $\mathrm{Zr}$ and Hf depletions (Klemme et al. 2005). These traceelement features are most likely to be inherent to the parental magma source of these rocks. More importantly, the analysed zircon grains mostly yield positive $\varepsilon_{\mathrm{Hf}}(\mathrm{t})$ values $(0$ to +4.7$)$, except for five spots that have negative $\varepsilon_{\mathrm{Hf}}(\mathrm{t})$ values $(-1.6$ to -0.2$)$ and $\mathrm{T}_{\mathrm{DM}}{ }^{\mathrm{C}}$ that vary from $1540 \mathrm{Ma}$ to $1136 \mathrm{Ma}$ (Table 3), indicative of a depleted mantle source which was contaminated by crustal components. However, as discussed in Section 5.b.1, the Datong pluton has experienced a minor amount of crustal contamination. In summary, the origin of the parental magma of the Datong pluton is most reasonably associated with the melting of enriched lithospheric mantle.

\section{5.c. Summary and tectonic implications}

\section{5.c.1. Tectonic environment}

As mentioned in Sections 4.a and 5.b, the Datong pluton, the largest of the Palaeozoic composite intrusive bodies within the NWKT, is characterized by high-K calc-alkaline to shoshonitic affinities. There is a general consensus that high-K calc-alkaline granitic magmas could be formed both in continental arc and in post-collisional settings (Pitcher, 1997). However, they are not necessarily explained as the products of the subduction processes within continental arc, as post-collisional extensional settings are also reasonable alternatives (Pitcher, 1997; Bonin, 2004). As mentioned in Section 5.b.2, petrogenetic analysis reveals the Datong pluton is derived from an enriched lithospheric mantle source. Its felsic rock types are due to magma differentiation by fractional crystallization with subordinate crustal contamination, sharing geochemical analogies with the magmatic suites of the monzodiorite-monzonite-syenite-monzogranite suite with high-K calc-alkaline to shoshonitic traits in the Central Alps (Bonin, 2004), which typifies magmatism in a post-collisional setting. Moreover, as discussed below and in the following section, from the geochronological and geological data, the Datong pluton was emplaced after the subduction event had ceased in the WKOB. Additionally, the Datong intrusive rocks are comparable to post-collisional granitoids of Frost et al. (2001), especially the Caledonian variety. This variety is reminiscent of the appinite-granite suites (Fowler et al. 2008; Ye et al. 2008; Murphy, 2013). The appinitic magmatism could occur in a local extensional zone in an intracontinental regime along faults, but could also form extensively in postsubduction or post-orogenic transtensional regimes induced by slab break-off or lithospheric delamination following termination of subduction in an arccontinent or continent-continent collision (Atherton \& Ghani, 2002; Castro et al. 2003; Fowler et al. 2008; Murphy, 2013), similar to that proposed for the rocks from the Datong pluton.

The above conclusion is reinforced by the following lines of evidence. (1) Recent zircon LA-ICP-MS U$\mathrm{Pb}$ dating by $\mathrm{Li} \&$ Zhang (2014) of the websterite in an ultramafic body from the Buziwan valley and dolerite in extrusive rocks from the Yixieke valley, which constitute the Kudi ophiolite, indicates that this ophiolite was formed during late Cambrian time (494 \pm 1 $-500 \pm 8 \mathrm{Ma}$ ). The Kudi ophiolite, which represents a dismembered fragment of Proto-Tethyan lithosphere, marks the oldest suture zone in the Tibetan Plateau (Matte et al. 1996; Pan, 1996; Mattern \& Schneider, 2000; Yuan et al. 2005) and is mainly composed of ultramafic rocks in the Buziwan valley and volcanic, volcaniclastic and sedimentary rocks of the Yishak Group in the Yixieke valley. The Kudi ophiolite was inferred by Yang et al. (1996) and Yuan et al. (2005) to have been formed in a supra-subduction zone environment. (2) The Yierba pluton consists mainly of 
quartz monzodiorite, quartz diorite and granodiorite. SHRIMP zircon U-Pb dating on quart monzodiorite indicates that this pluton was most likely emplaced during middle Cambrian time (513 $\pm 7 \mathrm{Ma}$ ) (Liu et al. 2014). These granitoids exhibit arc affinities related to the subduction of the Proto-Tethys oceanic crust (Liu et al. 2014). (3) The Kegang pluton, east of the Datong pluton (Fig. 1), is composed of quartz monzodiorite, diorite and quart diorite and formed during early Cambrian time (K-Ar age of $528 \mathrm{Ma}$; Jiang et al. 1999). The Kegang granitoids also show arc affinities (Jiang et al. 1999, 2002), which implies that the Proto-Tethys oceanic crust was already subducting during early Cambrian time. (4) Late Ordovician (c. $450 \mathrm{Ma}{ }^{39} \mathrm{Ar} /{ }^{40} \mathrm{Ar}$ hornblende age) shearing deformation developed along the Kudi suture zone between the NWKT and SWKT (Zhou et al. 2000; Xiao et al. 2005). (5) As documented from the petrogenesis of the Bulong, Qiukesu, North Kudi and Buya granitoids and their enclaves, the tectonic regime during late Cambrian - Silurian time was most likely associated with post-orogenic gravitational collapse following an episode of crustal thickening (Ye et al. 2008; Jia et al. 2013; Wang et al. 2013; Liu et al. 2014). (6) Silurian strata are absent and red molasses sediments were deposited in the Devonian in the WKOB (Pan, 1996). We therefore propose that the Datong pluton was emplaced in a post-collisional setting following the termination of subduction in response to slab break-off.

\section{5.c.2. Subduction polarity}

Consensus has been reached in recent years (Matte et al. 1996; Pan, 1996; Jiang et al. 1999, 2002; Mattern \& Schneider, 2000; Xiao et al. 2002, 2005; Wang, 2004; Li, Ji \& Yang, 2008; Ye et al. 2008; Liao et al. 2010; Jia et al. 2013; Liu et al. 2014) that an active continental margin developed along the southern boundary of the Tarim Craton during the Palaeozoic Era. However, controversy still exists regarding the subduction polarity of the Proto-Tethys Ocean within the WKOB. Some researchers (Matte et al. 1996; Pan, 1996; Mattern \& Schneider, 2000; Liao et al. 2010; Jia et al. 2013; Liu et al. 2014) have argued for southwards-directed subduction of the Proto-Tethys Ocean beneath the northern part of the SWKT, mainly based on the presence of Palaeozoic arc granitoids in the northern part of the SWKT and south of the Kudi suture and the absence of Palaeozoic arc granitoids in the NWKT. This argument interprets the Palaeozoic sedimentary succession in the southern Tarim Craton as passive margin sediments. In contrast, other researchers have argued for northwards-directed subduction of the Proto-Tethys Ocean beneath the southern part of the NWKT (Deng, 1995; Wang, 2004; Li, Ji \& Yang, 2008; Ye et al. 2008), mainly according to the extensive amount of Palaeozoic intermediate-acid intrusive and extrusive rocks developed to the north of the Kudi suture. In this model, the southern part of the Tarim Craton is an active margin related to northwards- directed subduction of the Proto-Tethys Ocean during Palaeozoic time. Alternatively, Xiao et al. $(2002,2005)$ proposed a change in the subduction polarity during late Cambrian - Early Ordovician south-dipping subduction of the Proto-Tethys Ocean and Middle Ordovician northwards-directed subduction.

The Palaeozoic tectonic evolution of the WKOB is obviously relevant to the formation and evolution of the Palaeozoic granitoids. Because of the presence of a continental rift succession before early Palaeozoic time on the southern border of the Tarim Craton and the lack of magmatic activity during Cambrian - earliest Ordovician time within the southern part of the Tarim Craton and the NWKT (Fig. 13), the early Palaeozoic southern Tarim Craton has been considered to be a passive continental margin (Xiao et al. 2002, 2005). However, recent highly precise geochronological data (Liao et al. 2010; Yu et al. 2011; Jia et al. 2013; Liu et al. 2014) have documented widespread Palaeozoic magmatism during c. 513-420 Ma in the NWKT. In particular, Cui et al. (2007a) reported arc granitoids with a SHRIMP zircon U-Pb age of $502 \pm 9 \mathrm{Ma}$ in the southern Tarim Craton. Additionally, Ye et al. (2008) dated a high-Ba-Sr granite with a SHRIMP zircon $\mathrm{U}-\mathrm{Pb}$ age of $430 \pm 12 \mathrm{Ma}$ at the south of Hetian City in the Tiekelike region. This granite is interpreted as a product of partial melting of an old crustal source with only minor contamination from coeval mafic magma which followed the terrane accretion in the southern Tarim Craton and the beginning of a post-orogenic collapse phase in the Palaeozoic WKOB (Fig. 1b). These Palaeozoic igneous rocks therefore likely represent subduction-related magmatic activity related to northwards-directed subduction. In this model, the Palaeozoic NWKT and the southern Tarim Craton are interpreted to be an active continental margin associated with northwards-directed subduction of the Proto-Tethys Ocean during Palaeozoic time (Fig. 13b; Deng, 1995; Xiao et al. 2002, 2005; Wang, 2004; Li, Ji \& Yang, 2008; Ye et al. 2008). Our identification of the Late Ordovician appinite-granite complex (459-448 Ma) in the Datong region of the NWKT indicates the area formed a post-collisional setting following the termination of subduction (Fig. 13c). We can therefore infer that the subduction initiated no later than $c .513 \mathrm{Ma}$ and likely lasted until Late Ordovician time (459-448 Ma) in the southern Tarim Craton and the NWKT. This conclusion is further supported by unconformity evidence. From analysis of seismic logging and outcrop data, Lin et al. (2012) recognized three major widespread angular to minor angular unconformities in the south-central Tarim Craton $-\mathrm{T}_{\mathrm{g} 5-2}$, $\mathrm{T}_{\mathrm{g} 5}$ and $\mathrm{T}_{\mathrm{g} 3}$ - which are mainly related to tectonic events or compressive uplift during Middle - early Late Ordovician time, the end of Late Ordovician time and the end of Middle Devonian time, respectively. The development of unconformity $\mathrm{T}_{\mathrm{g} 5-2}$ is clearly in good agreement with the emplacement timing of the Datong pluton. Consequently, we speculate that the Datong magmatism was a response to slab break-off; 
(a) $>530 \mathrm{Ma} \longrightarrow \mathrm{N}$

SW

Kunlun Terrane Proto-Tethys Terrane and Tarim Craton

(b) $~ 530-502 \mathrm{Ma}$

Divergent double subduction on both sides of SW the single Proto-Tethys Oceanic slab

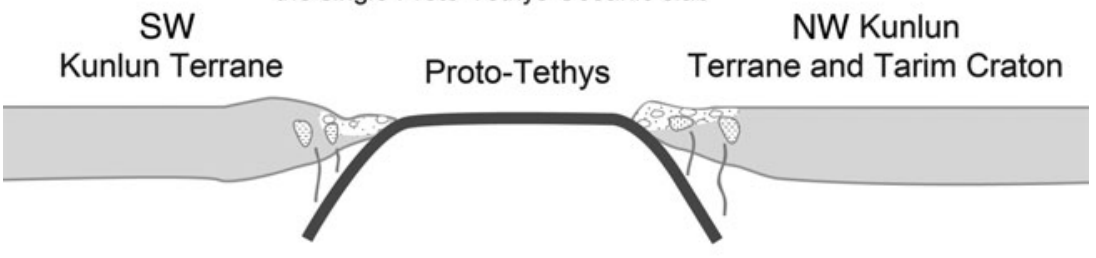

(c) $459-448 \mathrm{Ma}$

Closure of the Proto-Tethys causing the soft collision, cessation of subduction, break-off of the oceanic slab SW

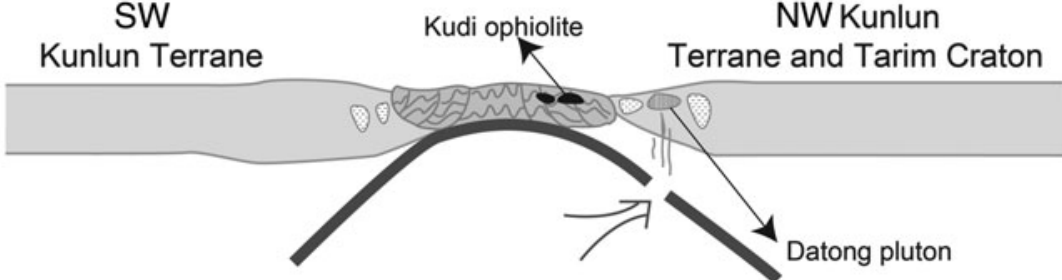

(d) $443-420 \mathrm{Ma}$

Detachment and sinking of the Proto-Tethys Oceanic lithosphere SW Kunlun Terrane NW Kunlun Terrane and Tarim Craton

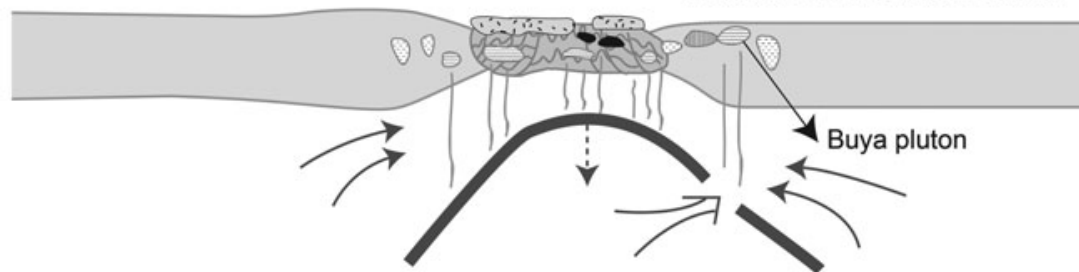

Figure 13. Simplified geodynamic and petrogenetic models showing the tectonic evolution of a divergent double-subduction system in the WKOB. See text for explanation.

termination of the northwards-directed subduction of the Proto-Tethys Ocean beneath the NWKT resulted in a type of fore-bulge uplift in the southern Tarim Craton (Lin et al. 2012).

As mentioned above, the SWKT is characterized by a gneiss complex and the Kudi ophiolite mélange. According to previously published data, some ultramafic and mafic rocks (494 $\pm 1 \mathrm{Ma}$ ) were tectonically emplaced in the SWKT, forming the Kudi ophiolite mélange. This mélange has been interpreted as a significant tectonic line separating the NWKT and the SWKT and likely represents the remnants of a suture related to the Proto-Tethys Ocean (Pan, 1996), im- plying the ocean was still wide at $494 \pm 1$ Ma. New highly precise geochronological data have been compiled in Figure 1b. Especially noteworthy features include two discrete igneous episodes - one at c. $500 \mathrm{Ma}$ with arc affinity and one at $c .447-431 \mathrm{Ma}$ with postorogenic setting (Cui et al. 2006a , b, 2007a, b; Zhang et al. 2007) - along with c. 450-428 Ma metamorphic overprinting (Matte et al. 1996; Zhou et al. 2000; $\mathrm{Xu}$ et al. 2007). This makes it plausible that the SWKT and the NWKT amalgamated at this time, and dextral E-W-shearing deformation developed along the Kudi suture zone (Zhou et al. 2000; Xiao et al. 2005) within the SWKT. A northern-directed 
subduction polarity in the model does not seem to account for the widespread Palaeozoic magmatic and metamorphic expressions within the SWKT situated to the south of the Kudi suture (Fig. 1b). Recently, Zhu et al. (2016) obtained two LA-ICP-MS zircon U$\mathrm{Pb}$ ages of $530 \mathrm{Ma}$ and $515 \mathrm{Ma}$ for a granitic porphyry and a monzogranite with arc affinity, respectively, in the TT, neither of which is compatible with the model of northern-directed subduction of the ProtoTethys Ocean. The records of the arc magmatism in the SWKT and TT suggest that the Proto-Tethys oceanic crust likely subducted beneath the SWKT and that the SWKT was an active continental margin at almost the same time as the NWKT during Palaeozoic time. A divergent double-subduction system is therefore tentatively proposed to explain the symmetrical distribution of broadly concurrent subductionrelated and post-orogenic magmatic records on opposite terranes separated by a significant tectonic line (the Kudi ophiolite mélange) during the time interval c. 530-420 Ma.

In the divergent double-subduction model, as exemplified in the Palaeozoic Lachlan Fold Belt in southeastern Australia (Soesoo et al. 1997) and the Proterozoic Jiangnan Orogen in South China (Zhao et al. 2015), four stages of tectonic evolution have been reconstructed as a probable scenario (Fig. 13): (1) the existence a palaeo-ocean, the Proto-Tethys Ocean, between the NWKT and SWKT during late Neoproterozoic (at least early Cambrian) time (Pan,1996; Mattern \& Schneider, 2000; Xiao et al. 2002, 2005; Zhang et al. 2007; Li, Ji \& Yang, 2008; Lin et al. 2012; Zhao \& Cawood, 2012), as evidenced by the riftrelated igneous and sedimentary clastic rocks and carbonate deposited on both the NWKT and SWKT and on the southern Tarim Craton (Zhang et al. 2007; Lin et al. 2012; Zhao \& Cawood, 2012); (2) the onset of divergent subduction along subduction zones on both sides of the single oceanic plate during the Cambrian, leading to the $c$. 530-502 Ma arc magmatism on the opposing terranes; (3) continued divergent subduction ultimately causing the closure of the ocean basin, soft collision of the NWKT and SWKT without involvement of continental deep subduction, high-grade metamorphism of continental crust and uplift/exhumation of high-grade metamorphic rocks (Soesoo et al. 1997; Zhao 2015), cessation of subduction, and breaking up of the oceanic slab on the north side due to continued slab pull through mineral changes at depth producing excess negative buoyancy, which created a gap that was filled with upwelling hot asthenosphere leading to partial melting of the overriding enriched lithosphere to generate the Datong pluton on the NWKT during Late Ordovician time (459-448 Ma); and (4) the subsequent detachment of the oceanic lithosphere from the overlying crust, inducing inflow of mantle material above the sinking oceanic slab and resulting in concomitant c. 450-428 Ma metamorphism (Zhou et al. 2000; $\mathrm{Xu}$ et al. 2007) and post-orogenic magmatism, such as the North Kudi A-type granites (Xiao et al. 2002; Liu et al. 2014) and the Buya high-Ba-Sr granites (Ye et al. 2008).

\section{Conclusions}

(1) The Datong pluton, the largest early Palaeozoic granitoid intrusion in the WKOB, is a typical appinite-granite complex and consists of diorites, quartz diorites, monzodiorites, quartz monzodiorites, monzonites, quartz monzonites, syenites, granodiorites and monzogranites. LA-ICP-MS zircon U-Pb dating yields crystallization ages of $459 \pm 3 \mathrm{Ma}$ for the quartz monzonites and $452 \pm 5$ Ma for the monzogranites, indicating a Late Ordovician age of emplacement.

(2) The geochemical data and the Sr, Nd and zircon Hf isotopic signatures suggest that the Datong appinite-granite complex was most likely derived from an enriched lithospheric mantle source.

(3) Fractional crystallization with minor crustal contamination was involved in the petrogenetic process of the Datong pluton.

(4) The Datong pluton was likely generated in a post-collisional setting following the termination of subduction associated with slab break-off. Considering the distribution and chronology of the Palaeozoic intrusions, such as Kegang, Bulong, Qiukesu, Yierba, North Kudi, Dongbake, Buya, Ayilixi and Warengzilafu granitoid plutons with ages of c. $420-530 \mathrm{Ma}$, and the Palaeozoic metamorphic overprinting in the WKOB, a divergent double-subduction model appears to best explain the evolution of the Proto-Tethys Ocean during early Palaeozoic time.

Acknowledgements. We are grateful to Professor Chad Deering, Editor, and Professor Brendan Murphy and two anonymous reviewers for their valuable comments which improved an earlier version of this paper. This work was funded by the 973 Program (grant no. 2014CB440801); the Geological Survey of China Geological Survey Projects (grant nos 1212011140056 and 12120113041000); and the China Scholarship Council. We thank Bin Yang, Libing Gu and Fang Ma for assistance with the whole-rock geochemical analysis; Dr Zhang Bo for assistance with the zircon CL imaging; Bin Wu and Zhaochu Hu for help with the LA-ICP-MS zircon U-Pb-Hf isotopic analyses; and Jinlong Ma for help with the $\mathrm{Sr}-\mathrm{Nd}$ isotopic analyses.

\section{References}

ANDERSEN, T. 2002. Correction of common lead in U-Pb analyses that do not report ${ }^{204} \mathrm{~Pb}$. Chemical Geology 192, 59-79.

Atherton, M. P. \& GhANI, A. A. 2002. Slab breakoff: a model for Caledonian, late Granite syn-collisional magmatism in the orthotectonic (metamorphic) zone of Scotland and Donegal, Ireland. Lithos 62, 65-85.

BachmanN, O., Dungan, M. A. \& Bussy, F. 2005. Insights into shallow magmatic processes in large silicic magma bodies: the trace element record in the Fish Canyon magma body, Colorado. Contributions to Mineralogy and Petrology 149, 338-49.

BAXTER, S. \& FEeLY, M. 2002. Magma mixing and mingling textures in granitoids: examples from the Galway Gran- 
ite, Connemara, Ireland. Mineralogy and Petrology 76, 63-74.

Bea, F., Montero, P. G., Gonzalez-Lodeiro, F., Talavera, C., Molina, J. F., Scarrow, J. H., Whitehouse, M. J. \& ZINGER, T. 2006. Zircon thermometry and U-Pb ion-microprobe dating of the gabbros and associated migmatites of the Variscan Toledo Anatectic complex, Central Iberia. Journal of the Geological Society 163, $847-55$.

Blichert-Toft, J. \& Albarède, F. 1997. The Lu-Hf isotope geochemistry of chondrites and the evolution of the mantle-crust system. Earth and Planetary Science Letters 148, 243-58.

Bonin, B. 2004. Do coeval mafic and felsic magmas in post-collisional to within-plate regimes necessarily imply two contrasting, mantle and crustal, sources? A review. Lithos 78, 1-24.

BoztuĞ, D., Arehart, G. B., Platevoet, B., Harlavan, Y. \& Bonin, B. 2007. High-K, calc-alkaline I-type granitoids from the composite Yozgat batholith generated in a post-collisional setting following continent-oceanic island arc collision in central Anatolia, Turkey. Mineralogy and Petrology 91, 191-223.

CAstro, A. 2013. Tonalite-granodiorite suites as cotectic systems: a review of experimental studies with applications to granitoid petrogenesis. Earth-Science Reviews 124, 68-95.

Castro, A., Corretge, L. G., De La Rosa, J. D., Fernandze, C., Lopez, S., Garcia-Moreno, O. \& Chacon, H. 2003. The appinite-migmatite complex of Sanabria, NW Iberian massif, Spain. Journal of Petro$\log y$ 44, 1309-44.

Chen, B., Jahn, B. M., AraKawa, Y. \& Zhai, M. G. 2004. Petrogenesis of the Mesozoic intrusive complexes from the southern Taihang Orogen, North China Craton: elemental and $\mathrm{Sr}-\mathrm{Nd}-\mathrm{Pb}$ isotopic constraints. Contributions to Mineralogy and Petrology 148, 489-501.

Cui, J. T., Wang, J. C., Bian, X. W., Luo, Q. Z., Zhu, H. P., WANG, M. C. \& Chen, G. C. 2007a. Zircon SHRIMP $\mathrm{U}-\mathrm{Pb}$ dating of the Dongbake gneissic tonalite in northern Kangxiwa. Geological Bulletin of China 26, 726-9 (in Chinese with English abstract).

Cui, J. T., Wang, J. C., Bian, X. W. \& Zhu, H. P. 2006 a. Geological characteristics of Early Paleozoic quartz diorite in the vicinity of Kangxiwar, West Kunlun, China and its zircon SHRIMP U-Pb dating. Geological Bulletin of China 25, 1450-7 (in Chinese with English abstract).

Cui, J. T., Wang, J. C., Bian, X. W., Zhu, H. P., Luo, Q. Z., YANG, K. J. \& WANG, M. C. 2007b. Zircon SHRIMP U-Pb dating of early Paleozoic granite in the Menggubao-Pushou area on the northern side of Kangxiwar. Geological Bulletin of China 26, 710-9 (in Chinese with English abstract).

Cui, J. T., Wang, J. C., Bian, X. W., Zhu, H. P. \& YAng, K. J. 2006b. Geological Characteristics of Early Paleozoic Amphibolite and Tonalite in Northern Kangxiwar. West, Kunlun, China and their zircon SHRIMP U-Pb dating. Geological Bulletin of China 25, 1441-9 (in Chinese with English abstract).

Cui, J. W., Guo, X. P., Ding, X. Z., Li, P. W. \& Zhang, X. W. 2006c. Mesozoic-Cenozoic deformation structures and their dynamics in the basin-range junction belt of the west Kunlun-Tarim basin. Earth Science Frontiers 13, 103-18 (in Chinese with English abstract).

Davies, J. H. \& Von BlanckenburG, F. 1995. Slab breakoff: a model of lithospheric detachment and its test in the magmatism and deformation of collisional oro- gens. Earth and Planetary Science Letters 129, 85102.

Deng, W. M. 1995. Geological features of ophiolite and tectonic significance in the Karakorum-west Kunlun Mts. Acta Petrologica Sinica S1, 98-111 (in Chinese with English abstract).

Douce, A. E. \& Johnston, A. D. 1991. Phase equilibria and melt productivity in the pelitic system: implications for the origin of peraluminous granitoids and aluminous granulites. Contributions to Mineralogy and Petrology 107, 202-18.

Fowler, M. B., Henney, P. J., Darbyshire, D. P. F. \& Greenwood, P. B. 2001. Petrogenesis of high $\mathrm{Ba}-\mathrm{Sr}$ granites: the Rogart pluton, Sutherland. Journal of the Geological Society 158, 521-34.

Fowler, M. B., Kocks, H., DArbyshire, D. P. F. \& Greenwood, P. B. 2008. Petrogenesis of high $\mathrm{Ba}-\mathrm{Sr}$ plutons from the Northern Highlands Terrane of the British Caledonian Province. Lithos 105, 129-48.

Frost, B. R., Barnes, C. G., Collins, W. J., Arculus, R. J., Ellis, D. J. \& Frost, C. D. 2001. A geochemical classification for granitic rocks. Journal of Petrology 42, 2033-48.

Gao, X. F., Xiao, P. X., Kang, L., Xi, R. G., Guo, L., Xie, C. R. \& YANG, Z. C. 2013. Origin of Datongxi pluton in the west Kunlun orogen: constraints from mineralogy, elemental geochemistry and zircon U-Pb age. Acta Petrological Sinica 29, 3065-79 (in Chinese with English abstract).

Griffin, W. L., Pearson, N. J., Belousova, E., Jackson, S. E., Van Achterbergh, E., O'Reilly, S. Y. \& SheE, S. R. 2000. The Hf isotope composition of cratonic mantle: LAM-MC-ICPMS analysis of zircon megacrysts in kimberlites. Geochimica et Cosmochimica Acta 64, 133-47.

Hu, Z. C., LiU, Y. S., GaO, S., LiU, W. G., Zhang, W., Tong, X. R., Lin, L., Zong, K. Q., Li, M., Chen, H. H., Zhou, L. \& YANG, L. 2012. Improved in situ Hf isotope ratio analysis of zircon using newly designed $\mathrm{X}$ skimmer cone and jet sample cone in combination with the addition of nitrogen by laser ablation multiple collector ICP-MS. Journal of Analytical Atomic Spectrometry 27, 1391-9.

Imaoka, T., Nakashima, K., Kamei, A., Hayasaka, Y., Ogita, Y., IkaWa, T., Itaya, T., Takahashi, Y. \& Kagami, H. 2014. Anatomy of the Cretaceous Hobenzan pluton, SW Japan: internal structure of a small zoned pluton, and its genesis. Lithos 208-9, 81-103.

Jackson, S. E., Pearson, N. J., Griffin, W. L. \& Belousova, E. A. 2004. The application of laser ablation-inductively coupled plasma-mass spectrometry to in situ U-Pb zircon geochronology. Chemical Geology 211, 47-69.

Jerram, D. \& Petford, N. 2011. The Field Description of Igneous Rocks. 2nd edition. West Sussex, UK: John Wiley \& Sons.

Ji, W. H., Li, R.S., Chen, S. J., He, S. P., Zhao, Z. M., Bian, X. W., Zhu, H. P., CUI, J. G. \& ReN, J. G. 2011. The discovery of Palaeoproterozoic volcanic rocks in the $\mathrm{Bu}$ lunkuoler Group from the Tianshuihai Massif in Xinjiang of Northwest China and its geological significance. Science China Earth Sciences 54, 61-72.

JiA, R. Y., JiAnG, Y. H., LiU, Z., ZhaO, P. \& ZhOU, Q. 2013. Petrogenesis and tectonic implications of early Silurian high-K calc-alkaline granites and their potassic microgranular enclaves, western Kunlun orogen, NW Tibetan Plateau. International Geology Review 55, 958-75. 
JiAnG, C. F., WANG, Z. Q. \& Li, J. Y. 2000. Opening-Closing Tectonics of Center Orogenic Belt. Beijing: Geological Publishing House.

JianG, Y. H., Rui, X. J., He, J. R., Guo, K. Y. \& Yang, W. Z. 1999. Tectonic type of caledonian granitoids and tectonic significance in the west Kunlun Mts. Acta Petrologica Sinica 15, 105-15 (in Chinese with English abstract).

Jiang, Y. H., Jiang, S. Y., Ling, H. F., Zhou, X. R., Rui, X. J. \& YANG, W. Z. 2002. Petrology and geochemistry of shoshonitic plutons from the western Kunlun orogenic belt, Xinjiang, northwestern China: implications for granitoid geneses. Lithos 63, 165-87.

KaYgusuz, A. \& ÖzTÜRK, M. 2015. Geochronology, Geochemistry, and Petrogenesis of the Eocene Bayburt Intrusions, Eastern Pontides. Office of Nuclear Energy, Turkey: evidence for lithospheric mantle and lower crustal sources in the high-K calc-alkaline magmatism. Journal of Asian Earth Sciences 108, 97-116.

Klemme, S., Prowatke, S., Hametner, K. \& Günther, D. 2005. Partitioning of trace elements between rutile and silicate melts: implications for subduction zones. Geochimica et Cosmochimica Acta 69, 2361-71.

LI, Q. G., LiU, S. W., WANG, Z. Q., WANG, D. S., Yan, Z., YAnG, K. \& Wu, F. H. 2011. Late Jurassic CuMo mineralization at the Zhashui-Shanyang District, South Qinling, China: constraints from Re-Os molybdenite and laser ablation-inductively coupled plasma mass spectrometry U-Pb zircon dating. Acta Geologica Sinica (English Edition) 85, 661-72.

LI, Q. G., Liu, S. W., Wang, Z. Q., Yan, Q. R., Guo, Z., Zhang, Z., Zheng, H., Jiang, C., Wang, T. \& ChU, Z. 2007. Geochemical constraints on the petrogenesis of the Proterozoic granitoid gneisses from the eastern segment of the Central Tianshan Tectonic Zone, northwestern China. Geological Magazine 144, 305-17.

LI, R. S., JI, W. H. \& YANG, Y. C. 2008. Geology of Kunlun Mountain and Adjacent Areas (in Chinese). Beijing: Geological Publishing House.

LI, T. F. \& ZhANG, J. X. 2014. Zircon LA-ICP-MS U-Pb ages of websterite and basalt in Kudi ophiolite and the implication, west Kunlun. Acta Petrologica Sinica 30, 2393-401.

Liang, X. R., Wei, G. J., Li, X. H. \& LiU, Y. 2003. Precise measurement of ${ }^{143} \mathrm{Nd} /{ }^{144} \mathrm{Nd}$ and $\mathrm{Sm} / \mathrm{Nd}$ ratios using multiple-collectors inductively couple plasma-mass spectrometer (MC-ICP-MS). Geochemica 32, 91-6 (in Chinese with English abstract).

LiaO, S. Y., Jiang, Y. H., Jiang, S. Y., Yang, W. Z., Zhou, Q., JIN, G. D. \& ZHAO, P. 2010. Subducting sedimentderived arc granitoids: evidence from the Datong pluton and its quenched enclaves in the western Kunlun orogen, northwest China. Mineralogy and Petrology 100, $55-74$.

Lin, C. S., Yang, H. J., Liu, J. Y., Rui, Z. F., CAI, Z. Z. \& ZhU, Y. F. 2012. Distribution and erosion of the Paleozoic tectonic unconformities in the Tarim Basin, Northwest China: Significance for the evolution of paleo-uplifts and tectonic geography during deformation. Journal of Asian Earth Sciences 46, 1-19.

Liu, Y. S., GaO, S., Hu, Z., GaO, C. G., Zong, K. Q. \& Wang, D. B. 2010. Continental and oceanic crust recycling-induced melt-peridotite interactions in the Trans-North China Orogen: U-Pb dating, Hf isotopes and trace elements in zircons from mantle xenoliths. Journal of Petrology 51, 537-71.

LiU, Z., JiAng, Y. H., Jia, R. Y., ZhaO, P., Zhou, Q., Wang, G. C. \& NI, C. Y. 2014. Origin of Middle Cambrian and
Late Silurian potassic granitoids from the western Kunlun orogen, northwest China: a magmatic response to the Proto-Tethys evolution. Mineralogy and Petrology 108, 91-110.

Ludwig, K. R. 2003. Isoplot/Ex, Version 3. A Geochronological Toolkit for Microsoft Excel: Berkeley. California: Geochronology Center Berkeley.

Lugmair, G. W. \& Marti, K. 1978. Lunar initial ${ }^{143} \mathrm{Nd} /{ }^{144} \mathrm{Nd}$ : differential evolution of the lunar crust and mantle. Earth and Planetary Science Letters 39, 34957.

MacPherson, C. G., Dreher, S. T. \& Thirlwall, M. F. 2006. Adakites without slab melting: high pressure differentiation of island arc magma, Mindanao, the Philippines. Earth and Planetary Science Letters 243, 58193.

ManiaR, P. D. \& Piccoli, P. M. 1989. Tectonic discrimination of granitoids. Geological Society of America Bulletin 101, 635-43.

Matte, P., Tapponnier, P., Arnaud, N., Bourjot, L., Avouac, J. P., Vidal, P., LiU, Q., Pan, Y. S. \& Wang, Y. 1996. Tectonics of Western Tibet, between the Tarim and the Indus. Earth and Planetary Science Letters 142, 311-30.

Mattern, F. \& Schneider, W. 2000. Suturing of the Protoand paleo-Tethys oceans in the western Kunlun (Xinjiang, China). Journal of Asian Earth Sciences 18, 63750.

Mattern, F., Schneider, W., Li, Y. A. \& Li, X. D. 1996. A traverse through the western Kunlun (Xinjiang, China): tentative geodynamic implications for the Paleozoic and Mesozoic. Geologische Rundschau 85, 705-22.

Middlemost, E. A. K. 1994. Naming materials in the magma/igneous rock system. Earth-Science Reviews 37, 215-24.

Miller, J. S., Matzel, J. E. P., Miller, C. F., Burgess, S. D. \& Miller, R. B. 2007. Zircon growth and recycling during the assembly of large, composite arc plutons. Journal of Volcanology and Geothermal Research 167, 282-99.

MurPhy, J. B. 2013. Appinite suites: A record of the role of water in the genesis, transport, emplacement and crystallization of magma. Earth-Science Reviews 119, 3559.

Murphy, J. B. \& Hynes, A. J. 1990. Tectonic control on the origin and orientation of igneous layering: an example from the Greendale Complex, Antigonish Highlands, Nova Scotia, Canada. Geology 18, 403-6.

Murphy, J. B., Hynes, A. J. \& Cousens, B. 1997. Tectonic influence on Late Proterozoic Avalonian magmatism: an example from the Greendale Comples, Antigonish Highlands, Nova Scotia, Canada. In The Nature of Magmatism in the Appalachian Orogen (eds A. K. Sinha, J. B. Whalen \& J. P. Hogan), pp. 255-74. Geological Society of America, Memoir 191.

Pan, Y. S. 1996. Geological Evolution of the Karakorum and Kunlun Mountains. Beijing, China: Seismological Press.

PeCcerillo, A. \& TaYlor, S. R. 1976. Geochemistry of Eocene calc-alkaline volcanic rocks from the Kastamonu area, northern Turkey. Contributions to Mineralogy and Petrology 58, 63-81.

Pitcher, W. S. 1997. The Nature and Origin of Granite. Verlag: Springer.

Prowatke, S. \& Klemme, S. 2005. Effect of melt composition on the partitioning of trace elements between titanite and silicate melt. Geochimica et Cosmochimica Acta 69, 695-709. 
Qu, J. F., Zhang, L. F., Ai, Y. L., Lv, Z., Wang, J. P., Zhou, H. \& WANG, S. 2007. Discovery and P-T path of high pressure granulite in Taxkorgan, western Kunlun and its tectonic significance. Science in China (series D) 37, 429-41 (in Chinese with English abstract).

RAPP, R. P. \& Watson, E. B. 1995. Dehydration melting of metabasalt at 8-32 kbar: implications for continental growth and crust-mantle recycling. Journal of Petrology 36, 891-931.

Rapp, R. P., XiaO, L. \& Shimizu, N. 2002. Experimental constraints on the origin of potassium-rich adakites in eastern China. Acta Petrologica Sinica 18, 293302.

SAmbridge, M. S. \& Compston, W. 1994. Mixture modeling of multi-component data sets with application to ion-probe zircon ages. Earth and Planetary Science Letters 128, 373-90.

SAwKA, W. N. 1988. REE and trace element variations in accessory minerals and hornblende from the strongly zoned McMurry meadows pluton, California. Transactions of the Royal Society of Edinburgh: Earth Sciences 79, $157-68$.

Sisson, T. W., Ratajeski, K., Hankins, W. B. \& Glazner, A. F. 2005. Voluminous granitic magmas from common basaltic sources. Contributions to Mineralogy and Petrology 148, 635-61.

Smith, E. I., SÁnchez, A., Walker, J. D. \& Wang, K. 1999. Geochemistry of mafic magmas in the hurricane Volcanic Field, Utah: implications for small- and largescale chemical variability of the lithospheric mantle. Journal of Geology 107, 433-48.

Söderlund, U., Patchett, P. J., Vervoort, J. D. \& IsACHSEN, C. E. 2004. The ${ }^{176} \mathrm{Lu}$ decay constant determined by $\mathrm{Lu}-\mathrm{Hf}$ and $\mathrm{U}-\mathrm{Pb}$ isotope systematics of Precambrian mafic intrusions. Earth and Planetary Science Letters 219, 311-24.

Soesoo, A., Bons, P. D., Gray, D. R. \& Foster, D. A. 1997. Divergent double subduction: tectonic and petrologic consequences. Geology 25, 755-8.

STEIGER, R. H. \& JÄGER, E. 1977. Subcommission on geochronology: convention on the use of decay constants in geo- and cosmochronology. Earth and Planetary Science Letters 36, 359-62.

Sun, S. S. \& McDonough, W. F. 1989. Chemical and isotopic systematics of oceanic basalts: implications for mantle composition and processes. In Magmatism in the Ocean Basins (eds A. D. Saunders \& M. J. Norry), pp. 313-45. Geological Society of London, Special Publication no. 42 .

Taylor, S. R. \& McLennan, S. M. 1985. The Continental Crust: its Composition and Evolution. Palo Alto, CA: Blackwell Scientific Publications.

Van Achterbergh, E., Ryan, C. G., Jackson, S. E. \& GRIFFIN, W. L. 2001. Data reduction software for LAICP-MS. In Laser-Ablation-ICPMS in the Earth Sciences (ed. P. Sylvester), pp. 239-43. Mineralogical Association of Canada, Short Courses, Vol. 29.

Wang, C., LiU, L., He, S. P., YANG, W. Q., CAO, Y. T., ZhU, X. H. \& LI, R. S. 2013. Early Paleozoic magmatism in west Kunlun: constraints from geochemical and zircon $\mathrm{U}-\mathrm{Pb}-\mathrm{Hf}$ isotopic studies of the Bulong granite. Chinese Journal of Geology 48, 997-1014 (in Chinese with English abstract).

Wang, C., Wang, Y. H., Liu, L., He, S. P., Li, R. S., Li, M., Yang, W. Q., CaO, Y. T., Meert, J. G. \& ShI, C. 2014. The Paleoproterozoic magmatic-metamorphic events and cover sediments of the Tiekelik Belt and their tectonic implications for the southern margin of the Tarim Craton, northwestern China. Precambrian Research 254, 210-25.

WANG, Z. H. 2004. Tectonic evolution of the western Kunlun orogenic belt, western China. Journal of Asian Earth Sciences 24, 153-61.

WATSON, E. B. \& HARrison, T. M. 1983. Zircon saturation revisited: temperature and composition effects in a variety of crustal magma types. Earth and Planetary Science Letters 64, 295-304.

WendT, I. \& CARL, C. 1991. The statistical distribution of the mean squared weighted deviation. Chemical Geo$\log y \mathbf{8 6}, 275-85$.

Whitney, D. L. \& Evans, B. W. 2010. Abbreviations for names of rock-forming minerals. American Mineralogist 95, 185-7.

Xiao, B., Li, Q. G., LiU, S. W., Wang, Z. Q., Yang, P. T., Chen, J. L. \& XU, X. Y. 2014. Highly fractionated Late Triassic I-type granites and related molybdenum mineralization in the Qinling orogenic belt: geochemical and $\mathrm{U}-\mathrm{Pb}-\mathrm{Hf}$ and $\mathrm{Re}-\mathrm{Os}$ isotope constraints. Ore Geology Reviews 56, 220-33.

Xiao, W. J., Windley, B. F., Hao, J. \& Li, J. L. 2002. Arc-ophiolite obduction in the Western Kunlun Range (China): implications for the Palaeozoic evolution of central Asia. Journal of the Geological Society 159, 517-28.

Xiao, W. J., Windley, B. F., LiU, D. Y., Jian, P., LiU, C. Z., YUAN, C. \& SUN, M. 2005. Accretionary tectonics of the Western Kunlun Orogen, China: a Paleozoicearly Mesozoic, long-lived active continental margin with implications for the growth of southern Eurasia. Journal of Geology 113, 687-705.

Xu, Z. Q., QI, X. X., YANG, J. S., Ji, S. C., LI, H. B. \& Chen, F. Y. 2007. Senses and timings of two kinds of shear in the Kangxiwar Strike-Slip Shear Zone. West, Kunlun, and their tectonic significance. Geological Bulletin of China 26, 1252-61 (in Chinese with English abstract).

Yang, J. S., Robinson, P. T., Jiang, C. F. \& Xu, Z. Q. 1996. Ophiolites of the Kunlun Mountains, China and their tectonic implications. Tectonophysics $\mathbf{2 5 8}$ 215-31.

Ye, H. M., Li, X. H., Li, Z. X. \& Zhang, C. L. 2008. Age and origin of high $\mathrm{Ba}-\mathrm{Sr}$ appinite-granites at the northwestern margin of the Tibet Plateau: implications for early Paleozoic tectonic evolution of the Western Kunlun orogenic belt. Gondwana Research 13, 126-38.

Yin, A. \& Harrison, T. M. 2000. Geologic evolution of the Himalayan-Tibetan orogen. Annual Review of Earth and Planetary Sciences 28, 211-80.

Yu, X. F., Sun, F. Y., Li, B. L., Ding, Q. F., Chen, G. J., Ding, Z. J., Chen, J. \& Huo, L. 2011. Caledonian diagenetic and metallogenic events in Datong district in the western Kunlun: evidences from LA-ICP-MS zircon U$\mathrm{Pb}$ dating and molybdenite Re-Os dating. Acta Petrologica Sinica 27, 1770-8.

Yuan, C., Sun, M., Zhou, M. F., XiaO, W. J. \& Zhou, H. 2005. Geochemistry and petrogenesis of the Yishak Volcanic Sequence, Kudi Ophiolite, West, Kunlun (NW China): Implications for the magmatic evolution in a subduction zone environment. Contributions to Mineralogy and Petrology 150, 195-211.

Zhang, C. L., Lu, S. N., Yu, H. F. \& Ye, H. M. 2007. Tectonic evolution of the Western Kunlun orogenic belt in northern Qinghai-Tibet Plateau: Evidence from zircon SHRIMP and LA-ICP-MS U-Pb geochronology. Science in China Series D: Earth Sciences 50, 825-35. 
ZhaO, G. C. 2015. Jiangnan orogen in South China: developing from divergent double subduction. Gondwana Research 27, 1173-80.

Zhao, G. C. \& Cawood, P. A. 2012. Precambrian geology of China. Precambrian Research 222-3, 13-54.

Zhou, H., Chu, Z. Y., Li, J. L., Hou, Q. L., Wang, Z. H. \& FANG, A. M. 2000. ${ }^{40} \mathrm{Ar} /{ }^{39} \mathrm{Ar}$ dating of ductile shear zone in Kuda, west Kunlun, Xinjiang. Scientia Geologica Sinica 35, 233-9 (in Chinese with English abstract).
Zhu, J., Li, Q. G., Wang, Z. Q., Tang, H. S., Chen, X. \& XIAO, B. 2016. Magmatism and tectonic implication of early Cambrian granitoid plutons in Tianshuhai Terrane of the Western Kunlun Orogenic Belt, Northwest China. Northwestern Geology 49, 1-18 (in Chinese with English abstract).

Zindler, A. \& Hart, S. 1986. Chemical geodynamics. Annual Review of Earth and Planetary Sciences 14, 493571. 